\title{
Biosynthesis of Saxitoxin in Marine Dinoflagellates: An Omics Perspective
}

\author{
Muhamad Afiq Akbar ${ }^{1}$, Nurul Yuziana Mohd Yusof ${ }^{2}{ }^{\infty}$, Noor Idayu Tahir ${ }^{3}$, Asmat Ahmad ${ }^{4}$, \\ Gires Usup ${ }^{4}$, Fathul Karim Sahrani ${ }^{2}$ and Hamidun Bunawan ${ }^{5, *(D)}$ \\ 1 School of Bioscience and Biotechnology, Faculty of Science and Technology, Universiti Kebangsaan Malaysia, \\ Bangi 43600, Malaysia; muhdafiq.akbar@gmail.com \\ 2 Department of Earth Science and Environment, Faculty of Science and Technology, Universiti Kebangsaan \\ Malaysia, Bangi 43600, Malaysia; yuziana@ukm.edu.my (N.Y.M.Y.); fathul@ukm.edu.my (F.K.S.) \\ 3 Malaysian Palm Oil Board, No 6, Persiaran Institusi, Bandar Baru Bangi, Kajang 43000, Selangor, Malaysia; \\ idayu@mpob.gov.my \\ 4 University College Sabah Foundation, Jalan Sanzac, Kota Kinabalu 88100, Sabah, Malaysia; \\ asmat@ukm.edu.my (A.A.); gires@ukm.edu.my (G.U.) \\ 5 Institute of Systems Biology, Universiti Kebangsaan Malaysia, Bangi 43600, Malaysia \\ * Correspondence: hamidun.bunawan@ukm.edu.my; Tel.: +60-389-214-546
}

Received: 25 November 2019; Accepted: 9 January 2020; Published: 5 February 2020

check for updates

\begin{abstract}
Saxitoxin is an alkaloid neurotoxin originally isolated from the clam Saxidomus giganteus in 1957. This group of neurotoxins is produced by several species of freshwater cyanobacteria and marine dinoflagellates. The saxitoxin biosynthesis pathway was described for the first time in the 1980s and, since then, it was studied in more than seven cyanobacterial genera, comprising 26 genes that form a cluster ranging from $25.7 \mathrm{~kb}$ to $35 \mathrm{~kb}$ in sequence length. Due to the complexity of the genomic landscape, saxitoxin biosynthesis in dinoflagellates remains unknown. In order to reveal and understand the dynamics of the activity in such impressive unicellular organisms with a complex genome, a strategy that can carefully engage them in a systems view is necessary. Advances in omics technology (the collective tools of biological sciences) facilitated high-throughput studies of the genome, transcriptome, proteome, and metabolome of dinoflagellates. The omics approach was utilized to address saxitoxin-producing dinoflagellates in response to environmental stresses to improve understanding of dinoflagellates gene-environment interactions. Therefore, in this review, the progress in understanding dinoflagellate saxitoxin biosynthesis using an omics approach is emphasized. Further potential applications of metabolomics and genomics to unravel novel insights into saxitoxin biosynthesis in dinoflagellates are also reviewed.
\end{abstract}

Keywords: saxitoxin; dinoflagellates; omics technologies; transcriptomics; proteomics; metabolomics; genomics

\section{Introduction}

Saxitoxin (STX) is a type of paralytic shellfish toxin (PST), and it is the most potent naturally occurring neurotoxic alkaloid known [1]. This compound is classified as a neurotoxin due to its ability to interact with voltage-gated sodium, potassium, and calcium channels, and it modulates the flux of these ions into various cell types [2]. In general, saxitoxin is produced by freshwater cyanobacteria and marine dinoflagellates [3]. Since the first discovery of saxitoxin in Alaska butter clams (Saxidomus giganteus) in 1957 [4], a total of 57 natural saxitoxin analogues, varying mainly in the substitution of the side-group moieties (R1-R5) of the perhydropurine tricyclic backbone, were reported, and those found in dinoflagellates are listed in Table 1 . Based on the variation of the moieties, the saxitoxin can 
be classified as non-sulfated (neoSTX), mono-sulfated (GTX1-6), di-sulfated (C1-4), decarbamylated (dcSTX, dcneoSTX, dcGTXs1-4), and deoxy-decarbamoylated (doSTX, doGTXs1-3), causing different magnitudes of lethality [2,5]. Saxitoxin poisoning accounts for approximately 2000 cases worldwide annually with an average human mortality rate of $15 \%[3,6]$. Most cases of human saxitoxin toxicosis are associated with the ingestion of contaminated seafood, e.g., bivalves which accumulate saxitoxins produced by marine dinoflagellates. Aside from general safety concerns, the financial impact of saxitoxin outbreaks is substantial. Pertinent organizations (for instance, shellfisheries, shoreline establishments, and other fish-related businesses) are heavily affected with evaluated yearly expense of United States dollars (USD) \$895 million around the world utilized for monitoring and carrying out mitigation plans for saxitoxin-producing dinoflagellates [6].

Table 1. Structure of saxitoxin (STX) and side-group moieties produced by marine dinoflagellates. Modified and adapted from Wiese et al. [1].

\begin{tabular}{|c|c|c|c|c|c|c|c|}
\hline \multicolumn{8}{|c|}{ Structure of Saxitoxin (STX) } \\
\hline Analogues & $\mathbf{R}_{1}$ & $\mathbf{R}_{2}$ & $\mathbf{R}_{3}$ & $\mathbf{R}_{4}$ & $\mathbf{R}_{5}$ & Sources & Reference \\
\hline STX & $\mathrm{H}$ & $\mathrm{H}$ & $\mathrm{H}$ & $\mathrm{OCONH}_{2}$ & $\mathrm{OH}$ & $\begin{array}{l}\text { Alexandrium andersoni, } \\
\text { Alexandrium catenella, } \\
\text { Alexandrium fundyense, } \\
\text { Alexandrium tamarense, } \\
\text { Gymnodinium catenatum, } \\
\text { Pyrodinium bahamense }\end{array}$ & {$[7-12]$} \\
\hline neoSTX & $\mathrm{OH}$ & $\mathrm{H}$ & $\mathrm{H}$ & $\mathrm{OCONH}_{2}$ & $\mathrm{OH}$ & $\begin{array}{l}\text { A. andersoni, A. catenella, } \\
\text { A. fundyense, A. tamarense, } \\
\text { G. catenatum, P. bahamense }\end{array}$ & [7-12] \\
\hline \multicolumn{8}{|c|}{ Mono-sulfated } \\
\hline GTX1 & $\mathrm{OH}$ & $\mathrm{H}$ & $\mathrm{OSO}_{3}^{-}$ & $\mathrm{OCONH}_{2}$ & $\mathrm{OH}$ & $\begin{array}{c}\text { A. catenella, A. fundyense, } \\
\text { A. minutum, A. tamarense, } \\
\text { G. catenatum }\end{array}$ & {$[8-10,12,13]$} \\
\hline GTX2 & $\mathrm{H}$ & $\mathrm{H}$ & $\mathrm{OSO}_{3}^{-}$ & $\mathrm{OCONH}_{2}$ & $\mathrm{OH}$ & $\begin{array}{c}\text { A. catenella, A. fundyense, } \\
\text { A. minutum, Alexandrium } \\
\text { ostenfeldii, A. tamarense, } \\
\text { G. catenatum }\end{array}$ & {$[8,10,12-15]$} \\
\hline GTX3 & $\mathrm{H}$ & $\mathrm{OSO}_{3}{ }^{-}$ & $\mathrm{H}$ & $\mathrm{OCONH}_{2}$ & $\mathrm{OH}$ & $\begin{array}{l}\text { A. catenella, A. fundyense, } \\
\text { A. minutum, A. ostenfeldii, } \\
\text { A. tamarense, G. catenatum }\end{array}$ & {$[8,9,12-15]$} \\
\hline GTX4 & $\mathrm{OH}$ & $\mathrm{OSO}_{3}^{-}$ & $\mathrm{H}$ & $\mathrm{OCONH}_{2}$ & $\mathrm{OH}$ & $\begin{array}{l}\text { A. catenella, A. fundyense, } \\
\text { A. minutum, A. tamarense, } \\
\text { G. catenatum }\end{array}$ & {$[8-10,13,16]$} \\
\hline GTX5 (B1) & $\mathrm{H}$ & $\mathrm{H}$ & $\mathrm{H}$ & $\mathrm{OCONHSO}_{3}^{-}$ & $\mathrm{OH}$ & $\begin{array}{c}\text { A. catenella, A. fundyense, } \\
\text { A. tamarense, G. catenatum, } \\
\text { P. bahamense }\end{array}$ & [8-12] \\
\hline GTX6 (B2) & $\mathrm{OH}$ & $\mathrm{H}$ & $\mathrm{H}$ & $\mathrm{OCONHSO}_{3}^{-}$ & $\mathrm{OH}$ & $\begin{array}{l}\text { A. catenella, A. fundyense, } \\
\text { A. ostenfeldii, A. tamarense, } \\
\text { G. catenatum, P. bahamense }\end{array}$ & {$[8-12]$} \\
\hline
\end{tabular}


Table 1. Cont.

\begin{tabular}{|c|c|c|c|c|c|c|c|}
\hline \multicolumn{8}{|c|}{ Structure of Saxitoxin (STX) } \\
\hline Analogues & $\mathbf{R}_{1}$ & $\mathbf{R}_{\mathbf{2}}$ & $\mathbf{R}_{3}$ & $\mathbf{R}_{4}$ & $\mathbf{R}_{5}$ & \multirow[t]{2}{*}{ Sources } & \multirow[t]{2}{*}{ Reference } \\
\hline \multicolumn{6}{|c|}{ Di-sulfated } & & \\
\hline $\mathrm{C} 1$ & $\mathrm{H}$ & $\mathrm{H}$ & $\mathrm{OSO}_{3}^{-}$ & $\mathrm{OCONHSO}_{3}^{-}$ & $\mathrm{OH}$ & $\begin{array}{c}\text { A. catenella, A. fundyense, } \\
\text { A. ostenfeldii, A. tamarense, } \\
\text { G. catenatum }\end{array}$ & {$[8-10,12,15,17,18]$} \\
\hline $\mathrm{C} 2$ & $\mathrm{H}$ & $\mathrm{OSO}_{3}^{-}$ & $\mathrm{H}$ & $\mathrm{OCONHSO}_{3}^{-}$ & $\mathrm{OH}$ & $\begin{array}{c}\text { A. catenella, A. fundyense, } \\
\text { A. ostenfeldii, A. tamarense, } \\
\text { G. catenatum }\end{array}$ & {$[8-10,12,15,18]$} \\
\hline $\mathrm{C} 3$ & $\mathrm{OH}$ & $\mathrm{H}$ & $\mathrm{OSO}_{3}^{-}$ & $\mathrm{OCONHSO}_{3}^{-}$ & $\mathrm{OH}$ & A. catenella, G. catenatum & {$[14,19]$} \\
\hline $\mathrm{C} 4$ & $\mathrm{OH}$ & $\mathrm{OSO}_{3}^{-}$ & $\mathrm{H}$ & $\mathrm{OCONHSO}_{3}^{-}$ & $\mathrm{OH}$ & A. catenella, G. catenatum & {$[14,19]$} \\
\hline \multicolumn{8}{|c|}{ Decarbamoylated } \\
\hline dcSTX & $\mathrm{H}$ & $\mathrm{H}$ & $\mathrm{H}$ & $\mathrm{OH}$ & $\mathrm{OH}$ & $\begin{array}{c}\text { A. catenella, G. catenatum, } \\
\text { P. bahamense }\end{array}$ & {$[8,11,12]$} \\
\hline dcneoSTX & $\mathrm{OH}$ & $\mathrm{H}$ & $\mathrm{H}$ & $\mathrm{OH}$ & $\mathrm{OH}$ & A. tamarense & [20] \\
\hline dcGTX1 & $\mathrm{OH}$ & $\mathrm{H}$ & $\mathrm{OSO}_{3}^{-}$ & $\mathrm{OH}$ & $\mathrm{OH}$ & G. catenatum & [21] \\
\hline dcGTX2 & $\mathrm{H}$ & $\mathrm{H}$ & $\mathrm{OSO}_{3}^{-}$ & $\mathrm{OH}$ & $\mathrm{OH}$ & $\begin{array}{l}\text { A. catenella, A. fundyense, } \\
\text { G. catenatum }\end{array}$ & {$[8,12,17]$} \\
\hline dcGTX3 & $\mathrm{H}$ & $\mathrm{OSO}_{3}{ }^{-}$ & $\mathrm{H}$ & $\mathrm{OH}$ & $\mathrm{OH}$ & $\begin{array}{c}\text { A. catenella, A. fundyense, } \\
\text { G. catenatum }\end{array}$ & {$[8,12,17]$} \\
\hline dcGTX4 & $\mathrm{OH}$ & $\mathrm{OSO}_{3}^{-}$ & $\mathrm{H}$ & $\mathrm{OH}$ & $\mathrm{OH}$ & G. catenatum & [21] \\
\hline \multicolumn{8}{|c|}{ Deoxy-decarbamoylated } \\
\hline $\operatorname{doSTX}$ & $\mathrm{H}$ & $\mathrm{H}$ & $\mathrm{H}$ & $\mathrm{H}$ & $\mathrm{OH}$ & G. catenatum & [22] \\
\hline doGTX1 & $\mathrm{OH}$ & $\mathrm{H}$ & $\mathrm{OSO}_{3}^{-}$ & $\mathrm{H}$ & $\mathrm{OH}$ & G. catenatum & [22] \\
\hline doGTX2 & $\mathrm{H}$ & $\mathrm{H}$ & $\mathrm{OSO}_{3}^{-}$ & $\mathrm{H}$ & $\mathrm{OH}$ & G. catenatum & [22] \\
\hline \multicolumn{8}{|c|}{ Mono-hydroxybenzoate Analogues } \\
\hline GC1 & $\mathrm{H}$ & $\mathrm{H}$ & $\mathrm{OSO}_{3}^{-}$ & OCOPhOH & $\mathrm{OH}$ & G. catenatum & [21] \\
\hline GC2 & $\mathrm{H}$ & $\mathrm{OSO}_{3}^{-}$ & $\mathrm{H}$ & OCOPhOH & $\mathrm{OH}$ & G. catenatum & [21] \\
\hline GC3 & $\mathrm{H}$ & $\mathrm{H}$ & $\mathrm{H}$ & $\mathrm{OCOPhOH}$ & $\mathrm{OH}$ & G. catenatum & [21] \\
\hline${ }^{*}$ GC4 & $\mathrm{OH}$ & $\mathrm{H}$ & $\mathrm{OSO}_{3}^{-}$ & OCOPhOH & $\mathrm{OH}$ & G. catenatum & [19] \\
\hline${ }^{*}$ GC5 & $\mathrm{OH}$ & $\mathrm{OSO}_{3}{ }^{-}$ & $\mathrm{H}$ & OCOPhOH & $\mathrm{OH}$ & G. catenatum & [19] \\
\hline${ }^{*}$ GC6 & $\mathrm{OH}$ & $\mathrm{H}$ & $\mathrm{H}$ & $\mathrm{OCOPhOH}$ & $\mathrm{OH}$ & G. catenatum & [19] \\
\hline \multicolumn{8}{|c|}{ Di-hydroxybenzoate Analogues } \\
\hline${ }^{+}$GC1a & $\mathrm{H}$ & $\mathrm{H}$ & $\mathrm{OSO}_{3}{ }^{-}$ & DHB & $\mathrm{OH}$ & G. catenatum & [19] \\
\hline${ }^{+} \mathrm{GC} 2 \mathrm{a}$ & $\mathrm{H}$ & $\mathrm{OSO}_{3}{ }^{-}$ & $\mathrm{H}$ & DHB & $\mathrm{OH}$ & G. catenatum & [19] \\
\hline${ }^{+}$GC3a & $\mathrm{H}$ & $\mathrm{H}$ & $\mathrm{H}$ & DHB & $\mathrm{OH}$ & G. catenatum & [19] \\
\hline${ }^{+}$GC4a & $\mathrm{OH}$ & $\mathrm{H}$ & $\mathrm{OSO}_{3}^{-}$ & DHB & $\mathrm{OH}$ & G. catenatum & [19] \\
\hline+ GC5a & $\mathrm{OH}$ & $\mathrm{OSO}_{3}^{-}$ & $\mathrm{H}$ & DHB & $\mathrm{OH}$ & G. catenatum & [19] \\
\hline + GC6a & $\mathrm{OH}$ & $\mathrm{H}$ & $\mathrm{H}$ & DHB & $\mathrm{OH}$ & G. catenatum & [19] \\
\hline
\end{tabular}


Table 1. Cont.

\begin{tabular}{|c|c|c|c|c|c|c|c|}
\hline \multicolumn{8}{|c|}{ Structure of Saxitoxin (STX) } \\
\hline Analogues & $\mathbf{R}_{1}$ & $\mathbf{R}_{2}$ & $\mathbf{R}_{3}$ & $\mathbf{R}_{4}$ & $\mathbf{R}_{5}$ & Sources & Reference \\
\hline \multicolumn{8}{|c|}{ Sulfated Benzoate Analogues } \\
\hline${ }^{+} \mathrm{GC} 1 \mathrm{~b}$ & $\mathrm{H}$ & $\mathrm{H}$ & $\mathrm{OSO}_{3}^{-}$ & SB & $\mathrm{OH}$ & G. catenatum & [19] \\
\hline${ }^{+} \mathrm{GC} 2 \mathrm{~b}$ & $\mathrm{H}$ & $\mathrm{OSO}_{3}^{-}$ & $\mathrm{H}$ & $\mathrm{SB}$ & $\mathrm{OH}$ & G. catenatum & [19] \\
\hline${ }^{+} \mathrm{GC} 3 \mathrm{~b}$ & $\mathrm{H}$ & $\mathrm{H}$ & $\mathrm{H}$ & SB & $\mathrm{OH}$ & G. catenatum & [19] \\
\hline${ }^{+} \mathrm{GC} 4 \mathrm{~b}$ & $\mathrm{OH}$ & $\mathrm{H}$ & $\mathrm{OSO}_{3}^{-}$ & SB & $\mathrm{OH}$ & G. catenatum & [19] \\
\hline${ }^{+}$GC5b & $\mathrm{OH}$ & $\mathrm{OSO}_{3}^{-}$ & $\mathrm{H}$ & SB & $\mathrm{OH}$ & G. catenatum & [19] \\
\hline+ GC6b & $\mathrm{OH}$ & $\mathrm{H}$ & $\mathrm{H}$ & SB & $\mathrm{OH}$ & G. catenatum & [19] \\
\hline
\end{tabular}

Lately, studies of natural product biosynthesis were revolutionized by the unbiased and non-targeted universal detection, identification, and measurement of molecular fractions consisting of genes (genomics), messenger RNA (mRNA) (transcriptomics), proteins (proteomics), and metabolites (metabolomics), collectively dubbed as "omics" $[23,24]$. This is due to the capacity of omics technology and integrated methodologies to extract and appraise biomolecules at a global scale rather than targeting the individual genes, proteins, or metabolites via a traditional reductionist approach (Figure 1). A one-to-one interdisciplinary approach to linking the information element to its functional component was discussed by combining data obtained from one omics to another, e.g., transcriptomics and metabolomics in several microbial systems [25]. Integrated laboratory protocol allows the same sample to be utilized for several different omics analyses, creating an ideal platform for combined omics analysis to reveal co-regulation in biochemical networks [26]. The prospect of exploiting this strategy to unveil the complexity of saxitoxin biosynthesis by organisms of huge genomes (3-245 Gbp) such as dinoflagellates is promising. Hence, this review outlines and summarizes the recent progress of omics approach in understanding dinoflagellate saxitoxin molecular biosynthesis. Imperatives and challenges in adopting the methodology are also highlighted to allow its practical and impartial application for a sound and unequivocal biological interpretation. 


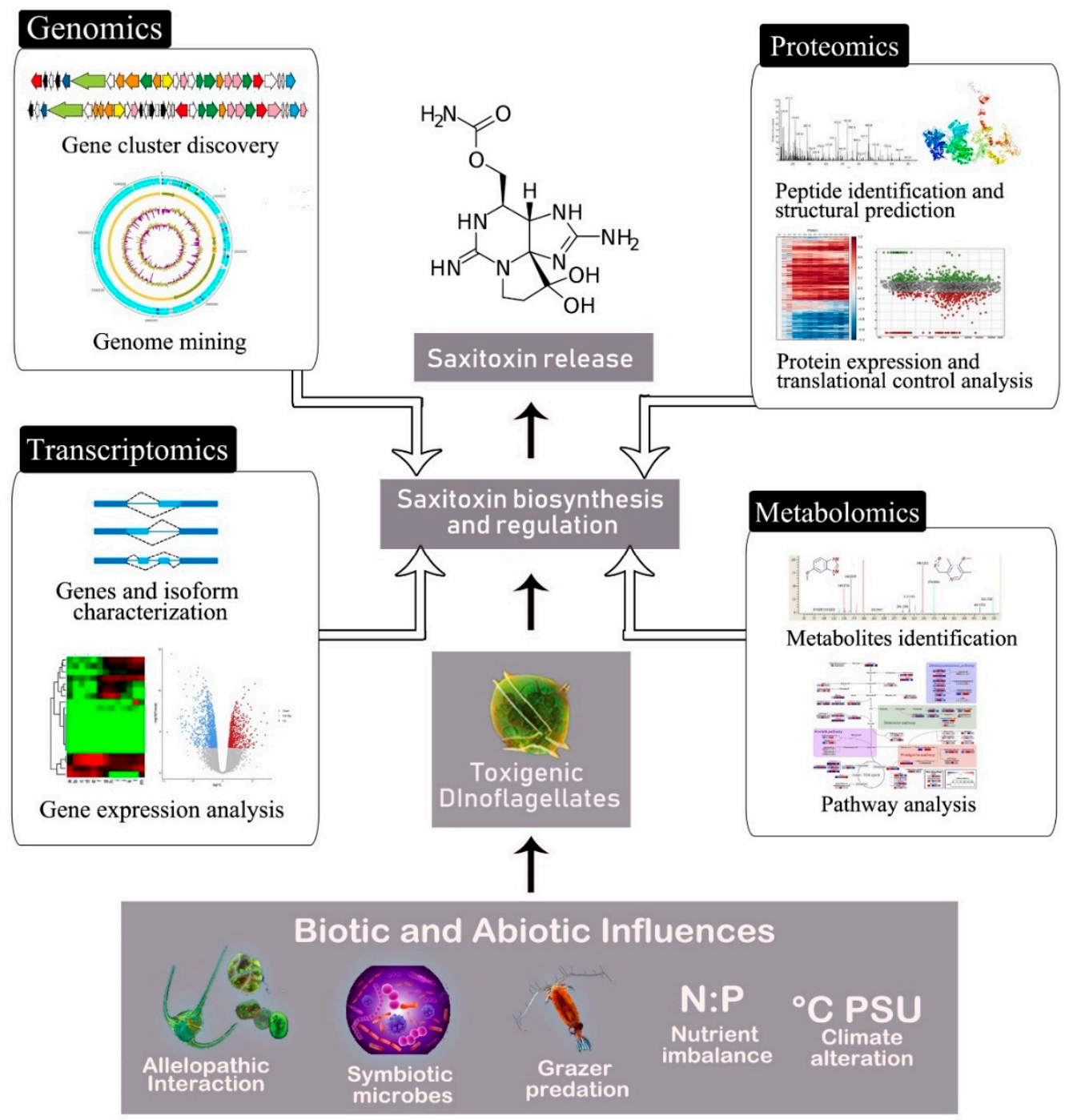

Figure 1. Decoding saxitoxin biosynthesis and its regulation via an omics approach. The production, release, and effect of saxitoxin by toxigenic dinoflagellates are influenced by their abiotic and biotic aquatic ecosystem components. This highly complex multi-organism and multi-stress environment within the context of saxitoxin synthesis can be grasped by the all-inclusive and high-throughput methods of omics.

\section{Overview of Saxitoxin Molecular Biosynthesis and Gene Cluster}

The first attempt to investigate the biosynthesis of saxitoxin was done by Shimizu et al. [27] using radioisotope tracing experiments. Their work suggested that saxitoxin is built from acetic acid, arginine, and S-adenosyl methionine (SAM), initiated by Claisen condensation of acetic acid and arginine. Later, the biosynthesis pathway for saxitoxin was revised and modified from the original proposed pathway based on the discovery and characterization of the saxitoxin gene cluster in saxitoxin-producing cyanobacteria via a genome walking approach and manual open reading frame (ORF) annotation [28]. The putative gene cluster for saxitoxin biosynthesis is encoded by 31 ORFs assigned to 26 proteins, stretching to $35 \mathrm{~kb}$ in length. This breakthrough was then followed by another finding of homologous gene clusters in several other cyanobacteria, ranging from $25.7 \mathrm{~kb}$ to $35 \mathrm{~kb}$ in length [29-31]. Based on the variation of gene clusters in saxitoxin-producing cyanobacteria, these genes were further classified into sets of core genes, regulator genes, tailoring genes, and transporter genes.

In the proposed saxitoxin biosynthesis pathway (Figure 2), the biosynthesis begins by polyketide synthase (PKS)-like enzymes encoded by the gene $s x t A$, which contains four catalytic domains of 
SAM-dependent methyltransferase ( $s x t A 1), \mathrm{GCN}-5$ related $N$-acetyltransferase ( $s x t A 2)$, acyl carrier protein ( $s x t A 3)$, and class II amidinotransferase (sxtA4). These PKS-like enzymes lack the trademark ketosynthase domain compared to the other typical PKSs [28]. SxtA initiates the biosynthesis via the following steps: (1) acetate from acetyl-coA is incorporated into an acyl carrier protein (ACP) which results in the formation of acetyl-ACP, (2) methylation of acetyl-ACP into propionyl-ACP by $s x t A 1$, and (3) Claisen condensation of propionyl-ACP with arginine, which results in the formation of 4-amino-3-oxo-guanidinoheptane. This is followed by the transfer of the amidino group from arginine into 4-amino-3-oxo-guanidinoheptane by the amidinotransferase $s x t G$. This reaction results in the formation of 4,7-diguanidino-3-oxoheptane (intermediate 4). Subsequent conversion of intermediate 4 into intermediate 5 is aided by a cytidine deaminase-like enzymes encoded by $s x t B$. Sterol desaturase enzyme encoded by sxtD then likely introduces a double bond between C- 1 and C- 5 of intermediate 4 , resulting in the 1,2-H shift between C-5 and C-6 (intermediate 5). Next, the $s x t S$, which has sequence similarity with nonheme iron 2-oxoglutarate-dependent dioxygenases, catalyzes the formation of intermediates 7 and 8 by performing successive epoxidation of the new double bond and the opening of the epoxide into an aldehyde with concomitant bicyclization. The subsequent reaction is executed by a short-chain alcohol dehydrogenase encoded by sxtU by reducing the terminal aldehyde group of intermediate 8 , thus resulting in the formation of intermediate 9 . The next reaction in saxitoxin biosynthesis involves the formation of the decarbamoylsaxitoxin (dcSTX) analogue by consecutive hydroxylation by phenylpropionate dioxygenase encoded by the gene $s x t H / T$. Oxygen reductase is required for the regeneration of these multicomponent enzymes of phenylpropionate dioxygenase after each catalytic reaction cycle. This requirement is fulfilled by a putative electron transport system encoded by the genes $s x t V$ and $s x t W$. Biosynthesis of the parent molecule of saxitoxin is completed by the transfer of a carbamoyl group onto the free hydroxyl group of C-13 facilitated by a putative $O$-carbamoyltransferase encoded by the genes $s x t I, s x t J$, and $s x t K$. Synthesis of other analogues from this saxitoxin parent molecule is aided by several tailoring enzymes. Different toxin profiles among species or strains of dinoflagellates are the outcome of the tailoring gene diversity. Analysis of several saxitoxin-producing cyanobacteria revealed the presence of several tailoring enzyme-encoding genes such as $s x t L, s x t N, s x t O$, and $s x t X$. Apart from these tailoring genes, a class of regulator genes is predicted to control the regulation of saxitoxin production in response to several environmental factors, as identified in the genome of C. raciborskii [28]. However, these genes were not found in other cyanobacterial genomes and, therefore, the saxitoxin regulator genes in the other cyanobacteria are thought to be located elsewhere in the genome, or their regulation may occur at the post-transcriptional level [3]. 


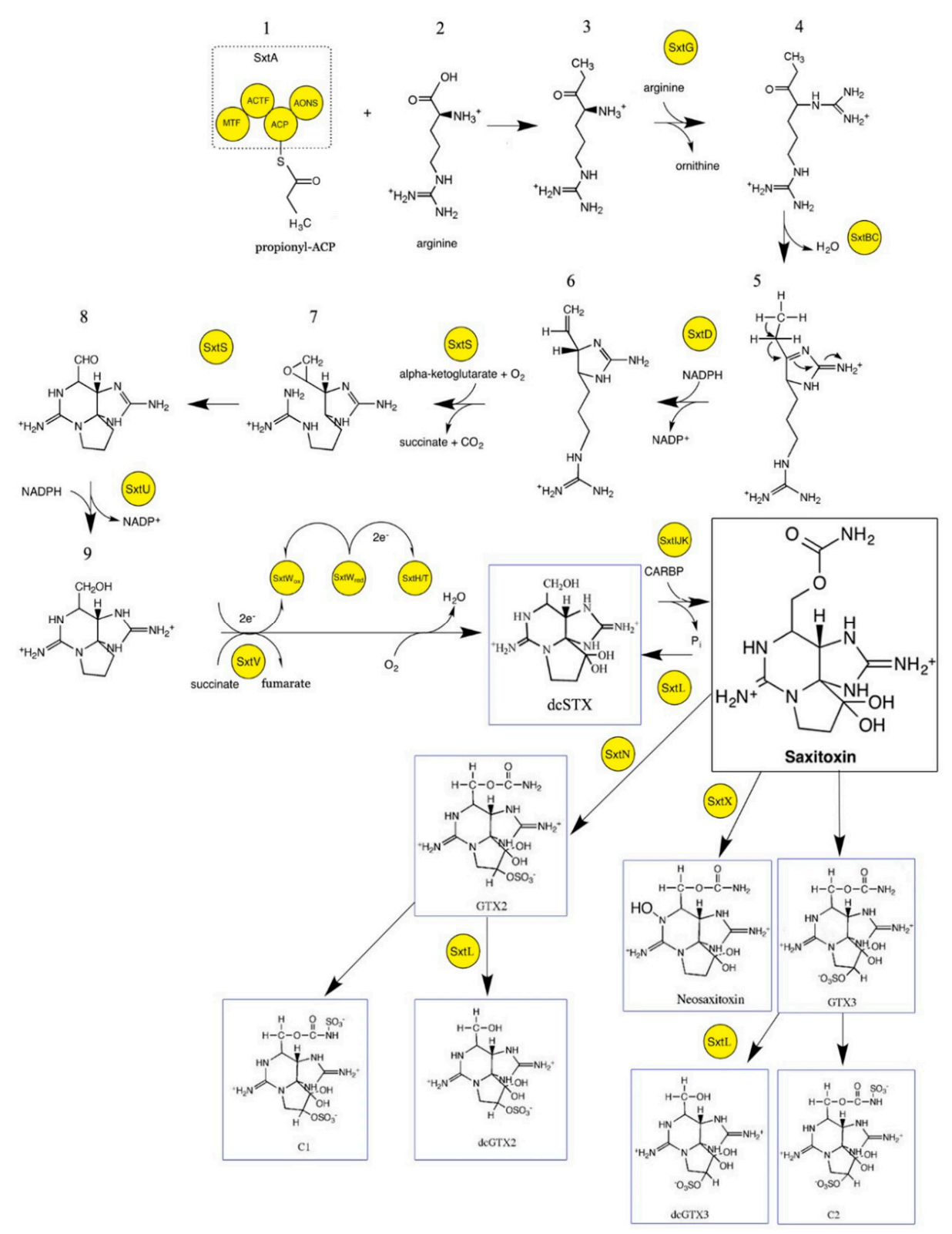

Figure 2. Putative pathway for saxitoxin biosynthesis in cyanobacteria. Proposed reactions are based on bioinformatics prediction incorporated from several studies [28-30]. A black box indicates a saxitoxin parent compound, and a blue box indicates selected saxitoxin analogues. Biosynthetic enzymes are highlighted in yellow circles.

\section{Recent Insight into Saxitoxin Biosynthesis through Transcriptomic Analysis}

The extraordinarily huge genome size of saxitoxin-producing dinoflagellates became a hindrance to genomics study, persuading researchers to turn to transcriptomics-based investigation as an alternative methodology that enables large-scale analysis of gene expression and transcriptome profiling [32,33]. Microarray and complementary DNA (cDNA) sequencing are the most common and preferred choices of transcriptomics approaches employed by researchers to investigate the saxitoxin biosynthesis in dinoflagellates. Since the identification of the saxitoxin gene cluster in cyanobacteria C. raciborskii T3 by Kellmann et al. [28], saxitoxin biosynthesis in dinoflagellates was inferred to follow the same pathway on the account of several intermediates identified in both cyanobacteria and dinoflagellates, suggesting the involvement of similar biosynthetic genes [34,35]. Since then, much effort was devoted to identifying candidate genes for saxitoxin biosynthesis in dinoflagellates using high-throughput 
transcriptome profiling, as well as a traditional PCR approach (Table 2). The earliest attempt to investigate the occurrence of these genes in dinoflagellates was undertaken by Yang et al. [36]. In silico search of sxt genes in the expressed sequence tag (EST) library of Alexandrium minutum that includes sequences from various physiological conditions and growth stages failed to identify any transcript with close homology to sxt genes. The inability to discover any homologous sxt genes in the A. minutum EST library is likely due to the limitation of available EST coverage [37].

Table 2. List of candidate sxt genes based on the cyanobacteria saxitoxin gene cluster and their occurrence in saxitoxin-producing dinoflagellates putatively identified through high-throughput transcriptome profiling and PCR. ACP—acyl carrier protein; PST—paralytic shellfish toxin.

\begin{tabular}{|c|c|c|c|c|c|}
\hline Role & Genes & Size (bp) & $\begin{array}{l}\text { Putative } \\
\text { Function }\end{array}$ & Species & Reference \\
\hline \multirow{13}{*}{ Core genes } & $\operatorname{sxt} A$ & $3702-3735$ & $\begin{array}{l}\text { Methylation, } \\
\text { loading of ACP, } \\
\text { Claisen } \\
\text { condensation }\end{array}$ & $\begin{array}{c}\text { A. minutum (AIN34673.1), } \\
\text { A. catanella (AIR95660.1), } \\
\text { A. tamarense (AIL29903.1), } \\
\text { A. fundyense (ADY62525.1), } \\
\text { A. ostenfeldii, Alexandrium } \\
\text { tamiyavanichii, G. catenatum } \\
\text { (AVV62437.1), P. bahamense } \\
\text { (QEX95300.1) }\end{array}$ & [38-49] \\
\hline & $s x t B$ & $954-975$ & Cyclization & $\begin{array}{l}\text { A. catenella, A. fundyense, } \\
\text { A. minutum, A. tamarense }\end{array}$ & {$[42,43,46,48]$} \\
\hline & $s x t C$ & $282-351$ & Regulatory & - & - \\
\hline & $s x t D$ & $756-798$ & Desaturation & A. catenella, A. tamarense & {$[42,46,48]$} \\
\hline & $s x t G$ & 1131 & Amidinotransfer & $\begin{array}{l}\text { A. minutum (AGC84341.1), } \\
\text { A. catenella (AGC84338.1), } \\
\text { A. fundyense (AGC84339.1), } \\
\text { A. tamarense (AGC84356.1), } \\
\text { G. catenatum (AGC84343.1), } \\
\text { P. bahamense (JAG92740.1) }\end{array}$ & {$[40,42-44,46,48,49]$} \\
\hline & $s x t H / T$ & $1002-1059$ & $\begin{array}{c}\mathrm{C}-12 \\
\text { hydroxylation }\end{array}$ & $\begin{array}{l}\text { A. catenella, A. fundyense, } \\
\text { A. minutum, A. tamarense }\end{array}$ & {$[42,43,46,48]$} \\
\hline & $s x t I$ & $1836-1923$ & Carbamoylation & $\begin{array}{l}\text { A. catenella, A. fundyense, } \\
\text { A. minutum, A. tamarense }\end{array}$ & {$[40,42,43,46,48]$} \\
\hline & sxtJ & $399-441$ & Regulatory & - & - \\
\hline & $s x t K$ & 162 & Regulatory & - & - \\
\hline & sxts & $723-798$ & Ring formation & $\begin{array}{l}\text { A. minutum, G. catenatum, } \\
\text { P. bahamense }\end{array}$ & {$[43,48]$} \\
\hline & sxtu & $774-777$ & $\begin{array}{l}\text { Short-chain } \\
\text { alcohol } \\
\text { dehydrogenase }\end{array}$ & $\begin{array}{l}\text { A. catenella, } \text { A. fundyense, } \\
\text { A. minutum, A. tamarense, } \\
\text { P. bahamense }\end{array}$ & {$[42,43,46,48]$} \\
\hline & $s x t V$ & $1650-1677$ & $\begin{array}{l}\text { Dioxygenase } \\
\text { reductase }\end{array}$ & - & - \\
\hline & $s x t W$ & $324-327$ & Ferredoxin & A. catenella & {$[46]$} \\
\hline \multirow{4}{*}{ Tailoring genes } & $s x t L$ & $1269-1296$ & Decarbamoylation & A. tamarense & [48] \\
\hline & $\operatorname{sxtN}$ & $825-906$ & Sulfotransferase & A. catenella, A. tamarense & {$[42,48]$} \\
\hline & $s x t O$ & $495-600$ & $\begin{array}{c}\text { PAPS } \\
\text { biosynthesis }\end{array}$ & A. catenella & {$[42,46]$} \\
\hline & $s x t X$ & $753-771$ & $\begin{array}{c}N-1 \\
\text { hydroxylation }\end{array}$ & $\begin{array}{c}\text { A. catenella, } \text { A. tamarense, } \\
\text { P. bahamense }\end{array}$ & {$[42,46,48]$} \\
\hline \multirow{2}{*}{ Regulator genes } & sxtY & 663 & $\begin{array}{l}\text { Signal } \\
\text { transduction }\end{array}$ & - & - \\
\hline & $s x t Z$ & 1350 & $\begin{array}{c}\text { Signal } \\
\text { transduction }\end{array}$ & A. catenella & {$[42,46]$} \\
\hline \multirow{2}{*}{ Transporter genes } & $s x t F / M$ & $1413-1455$ & Export of PSTs & $\begin{array}{l}\text { A. catenella, } A \text {. fundyense, } A \text {. } \\
\text { minutum, A. tamarense }\end{array}$ & {$[42,43,46,48]$} \\
\hline & sxtP & $1125-1479$ & Binding of PSTs & A. catenella, A. tamarense & {$[46,48]$} \\
\hline \multirow{3}{*}{ Unknown } & $s x t E$ & $360-474$ & Unknown & - & - \\
\hline & $\operatorname{sxt} Q$ & 774 & Unknown & - & - \\
\hline & $s x t R$ & $744-879$ & Unknown & A. fundyense, A. minutum & [43] \\
\hline
\end{tabular}


Using an RNA-sequencing (RNA-seq) approach, several full-length sxt genes present in the transcripts of dinoflagellates A. minutum and A. fundyense were discovered [43]. A cDNA sequence analysis showed that these $s x t$ genes in dinoflagellates differ from their cyanobacteria counterparts in terms of the presence of eukaryotic poly-A-tails, unique dinoflagellate spliced leader sequence, signal peptide, and GC content. These findings demonstrated that the sxt genes are indeed encoded in the genome of dinoflagellates and, thus, debunked the earlier belief that suggested the production of saxitoxin in dinoflagellates by intracellular Actinobacteria and Proteobacteria symbionts [6]. As the starting gene in saxitoxin biosynthesis, sxt $A$ became a main target for study. Uniquely, two different transcript families of $s x t A$ gene were identified in the $A$. fundyense transcriptome [43]. These two transcripts differed in their sequence length and encode different catalytic domains in which the longer transcript encodes all sxtA domains (sxtA1-sxtA4) as their cyanobacteria counterparts, while the shorter transcript encodes only domains $s x t \mathrm{~A} 1-s x t \mathrm{~A} 3$. Further assessment into the function of these genes led to the postulation that the long transcript of $s x t A 4$ might be directly involved in the biosynthesis of saxitoxin, as its occurrences were identified in many saxitoxin-producing dinoflagellates including Gymnodinium catenatum and Pyrodinium bahamense $[42,43,48]$. This is also in accordance with findings showing the correlation between gene sxtA4 copy number in A. minutum and A. ostenfeldii genomes and their saxitoxin contents [50,51]. The reports from these transcriptomic studies enabled researchers to perform in situ detection of saxitoxin-producing dinoflagellates [43,52,53]. A more extensive survey by Hackett et al. [48] showed that the C-terminal region of sxtA is found exclusively in saxitoxin-producing dinoflagellates. A recent probe into various dinoflagellate species transcriptome library data from Marine Microbial Eukaryote Transcriptome Sequencing Program (MMETSP) also showed that the occurrence of domain sxtA4 is exclusive to saxitoxin-producing dinoflagellates including G. catenatum and P. bahamense and is highly conserved without paralogues, while the domain sxtA1 showed a widespread distribution in non-saxitoxin-producing dinoflagellates [54]. A more profound investigation utilizing phylogenetic approach revealed the presence of three paralogues for domain sxtA1 with one of the paralogues forming a highly corroborated clade of saxitoxin-producing dinoflagellates. The authors speculated that the $s x t A$ originated from a common ancestor of Alexandrium spp., G. catenatum, and P. bahamense in the order of Peridiniales, 190 million years ago, based on similarity of the sxtA4 domain in those species of these taxa [54,55]. However, the phylogeny of domain $s x t A 1$ does not appear to be consistent with the species phylogeny of these taxa, indicating that the origin of this gene is more complex, and there is the possibility of several events of gene duplication resulting in formation of several paralogues. The events of gene duplication may also occur from the recycling of mature mRNA back into the genomes, which is termed "retroposition", resulting in the formation of retrogenes [56,57]. Retrogenes were widely studied for their involvement in dinoflagellate evolution during critical periods of extreme environmental changes, e.g., drastic temperature rise and fall, and they are associated with surprising characteristics, including their high persistence rate and their presence in large number in the genomes [56,58]. Nevertheless, the role of retroposition in shaping the evolution of saxitoxin and the formation of paralogues of domain sxtA1 remains unexplored. In contrast to earlier findings, domain $s x t A 4$ was identified in several genomes of non-toxic A. tamarense group III and Alexandrium australiense (previously known as A. tamarense group V) $[43,53,54]$. However, to the best of our knowledge, there is no report on the expression of domain $s x t A 4$ from non-toxic dinoflagellates at the mRNA level. Zhang et al. [42] stated that the $s x t A 4$ domain is still in the genomes of non-toxic mutant $A$. catanella, although the expression of this gene was not detected in the RNA-seq data and q-PCR analysis, indicating that this gene is not transcribed into mRNA. Murray et al. [54] also found out that domain sxtA4 is not detected in the transcriptome library of A. tamarense group III despite the presence of this domain in its genome [43]. This rather contradictory result might be due to the silencing of the saxitoxin biosynthesis gene cluster expression in non-saxitoxin-producing dinoflagellates. Several reports on the presence of silent biosynthetic gene clusters recently surfaced, including in several marine microorganism, although no report is yet found for dinoflagellates [59]. There is also another possibility of additional gene existence apart from 
the $s x t A 4$ domain, which are crucial for the biosynthesis of saxitoxin and which are absent in these non-toxic strains.

Recognizing that the putative genes involved in saxitoxin biosynthesis possess various homologues in other diverse classes of organisms, Hackett et al. [48] suggested that the combination of enzymatic reactions encoded by these genes in a particular arrangement would result in saxitoxin production in dinoflagellates. This hypothesis is also supported by a later transcriptome analysis of non-saxitoxin-producing Scrippsiella trochoidea dinoflagellate that documented 113 transcripts perceived as homologues of sxt genes, covering 17 of the 34 genes found in C. raciborskii sxt genes, including the short isoform of sxtA1-A3 [60]. Thus, the homologue of sxt genes in dinoflagellates except for domain $s x t A 4$ is not exclusive to toxin-producing species, and we hypothesize that these genes may function in regulating the cellular metabolism or synthesizing other secondary metabolites. For example, sxtI which encodes the protein $O$-carbamoyltransferase is known to be involved in the biosynthesis of other secondary metabolites such as antibiotics [61]. Since the identification of a complete saxitoxin biosynthesis gene cluster is still not accomplished in dinoflagellates, the role of $s x t A 4$ domains in some non-toxic strains cannot be further explained.

$S x t A$ and $s x t G$ are both characterized as core genes for the biosynthesis of saxitoxin in dinoflagellates, and they were studied extensively compared to other sxt genes (Table 2). The structure of several $s x t G$ mRNA transcripts was firstly described in detail by Orr et al. [44] with a structure similar to a previous $s x t A$ gene, including their monocistronic mRNA, typical eukaryotic poly(A) tails, and unique dinoflagellate spliced leader sequence, all encoded in a nuclear genome. The $s x t G$ genomic sequence contains a noncanonical intron that showed high interspecies and low intraspecies variability [44]. Hackett et al. [48] and Murray et al. [54] demonstrated that occurrences of sxtG are unique to dinoflagellates producing saxitoxin, including G. catenatum and P. bahamense, and it was not detected in any non-saxitoxin-producing dinoflagellates including those from the genus Alexandrium. However, the expression of $s x t G$ mRNA was detected in three non-saxitoxin-producing Alexandrium species, although no such gene was reported in dinoflagellates other than Alexandrium spp. and G. catenatum [44]. As no stop codon was observed in the sequence and a low genomic copy was amplified from its genome, the mRNA of $s x t G$ from non-saxitoxin-producing Alexandrium spp. detected in this study may not be functional. The possible interference from the use of different transcriptome profiling technologies and inconsistent harvesting times for each of the study cannot be ruled out. A more systematic and wider coverage of sequencing might be needed to address these rather varying results. Phylogeny analysis of dinoflagellate $s x t G$ genes formed a highly conserved and fully supported clade, separating the genus from other dinoflagellates and bacteria with amidinotransferase enzymes $[44,54]$. Selection analysis of $s x t G$ and other amidinotransferase branching also revealed that the $s x t G$ branch is under negative selection, whereas other phylogeny branches including dinoflagellate amidinotransferase clades showed a significant positive selection [54]. A similar pattern of natural selection also was observed in the sxtA1 clade that is made of saxitoxin-producing dinoflagellates [54].

Out of 14 "core" genes for saxitoxin biosynthesis characterized from cyanobacteria, only nine of these essential genes were putatively identified within saxitoxin-producing dinoflagellates with a certain degree of similarity (Table 2). Apart from $s x t A$ and $s x t G$, the role of these genes in the biosynthesis of dinoflagellates saxitoxin remains poorly understood. These genes were putatively identified based on the closest BLAST hits, and none of them were extensively described for their domain architecture and sequence analysis. These sxt genes (other than $s x t A$ and $s x t G$ ) might have different functions in dinoflagellates, as these genes align at lower significant levels to sxt genes from cyanobacteria [43]. Phylogenetic analysis in A. tamarense demonstrated that these three genes ( $s x t A$, $s x t G$, and $s x t B$ ) are closely related to cyanobacteria and catalyze in the first three steps of the saxitoxin biosynthesis [48]. Other dinoflagellate $s x t$ genes $(s x t D, s x t S, s x t U, s x t H / T$, and $s x t I)$ showed poor phylogenetic relationship with sxt genes from cyanobacteria, and these complicate understanding the origin of these genes [48]. Dinoflagellates might have a different set of genes for saxitoxin biosynthesis, and their evolution is independent from cyanobacteria. The current hypothesis on the origin of 
saxitoxin biosynthesis in dinoflagellates based on $s x t A$ and $s x t G$ suggests that $s x t$ genes were acquired independently in both dinoflagellates and cyanobacteria [6,44,48]. Considering collective results from Orr et al. [44] and Stuken et al. [43], sxt genes in dinoflagellates were acquired via horizontal gene transfer from Actinobacteria and Proteobacteria. Various aspects of the evolutionary relationship of dinoflagellates saxitoxin biosynthesis genes, including sources of these genes, phylogenetic inference, and events of horizontal gene transfer, were extensively reviewed by Orr et al. [6].

In addition to the identification of toxin synthesis genes based on the cyanobacteria gene cluster, comparative transcriptome analysis became a valuable tool for dissecting the role of differently expressed genes (DEGs) among similar biological samples under different biological conditions in order to obtain a wider perspective of saxitoxin gene discovery in dinoflagellates (Table 3). The differentially expressed genes between the toxin and non-toxin dinoflagellates strains can also provide useful insight into the expression of saxitoxin genes. Comparative transcriptome analysis using microarrays on toxic and non-toxic strains of $A$. minutum revealed novel candidate genes for saxitoxin biosynthesis [36]. However, due to the lack of a homology sequence for dinoflagellates, most of these genes remain unannotated. A more recent comparative transcriptome analysis using high-throughput RNA-sequencing of saxitoxin producing A. catenella and its non-toxic mutant revealed 35 differently expressed genes among these strains [42]. Among the DEGs, sxtA4 genes were downregulated in non-toxic mutants, further supporting the hypothesis for involvement of this gene in saxitoxin biosynthesis. Apart from that, other DEGs were found to be mainly associated with photosynthesis, carbon fixation, and amino-acid metabolism.

Intracellular toxin content in dinoflagellates is closely linked to nutritional status [62,63]. With this information in view, the microarray gene expression study found that most of the differently expressed genes are involved in the dinoflagellate core metabolic process with no immediate connection toward saxitoxin biosynthesis [62]. Nonetheless, two of the non-annotated genes showed a consistence regulation pattern with cellular saxitoxin content. Despite the numerous studies connecting nutritional status, for example, nitrogen and phosphorus with respect to cell saxitoxin content, this relationship is poorly portrayed with transcriptomics studies from saxitoxin-producing dinoflagellates of A. minutum, A. tamarense, and $A$. fundyense $[62,64,65]$. Altogether, these studies were unable to find the correlation between dinoflagellate core metabolism and its impact on saxitoxin biosynthesis. However, it is noteworthy that none of these studies utilized the recent next-generation RNA-sequencing approach with deeper transcriptome coverage, which may provide progressively significant outcome compared to previous techniques.

The degree of dependency to which dinoflagellates alter the saxitoxin production level under transcriptional responses is yet to be resolved. For example, the gene expression pattern for sxtA4 in A. catenella examined by RT-qPCR did not significantly change under different growth stages, even though the saxitoxin production was significantly altered [45]. A similar expression pattern was also observed in $s x t A$ and $s x t G$ genes in A. minutum [49]. Examination by RNA-seq on the $A$. catenella transcriptome also revealed that most of the putative toxin gene transcripts varied insignificantly at different toxin biosynthesis stages [46]. All these results might suggest that saxitoxin production is ultimately regulated at a translational or post-translational level. Only a small portion of dinoflagellates genes are now presumed to be regulated at the transcriptome level [46]. For instance, under nitrogen starvation, only 220 genes were found to be differentially expressed in the dinoflagellate Amphidinium carterae [66]. Similarly, RNA-sequencing of the dinoflagellate S. trochoidea revealed only 178 transcripts from a total of 107,415 contigs that were differentially expressed under nitrogen stress [60]. Lin [67] suggested that limited transcriptional regulation in dinoflagellates is likely due to the lack of histone proteins which are thought to regulate gene expression in eukaryotes. Several recent studies illustrated that histone proteins may regulate gene expression for the production of secondary metabolites in some fungi $[68,69]$. Even though genes that encode histone proteins were identified in the dinoflagellate transcriptome, including a full suite of histone proteins, these genes might be expressed at a lower level and may play a limited role in regulating the gene expression [70]. 
Table 3. Summary of major findings on saxitoxin molecular biosynthesis in dinoflagellates using transcriptomics approach. EST-expressed sequence tag.

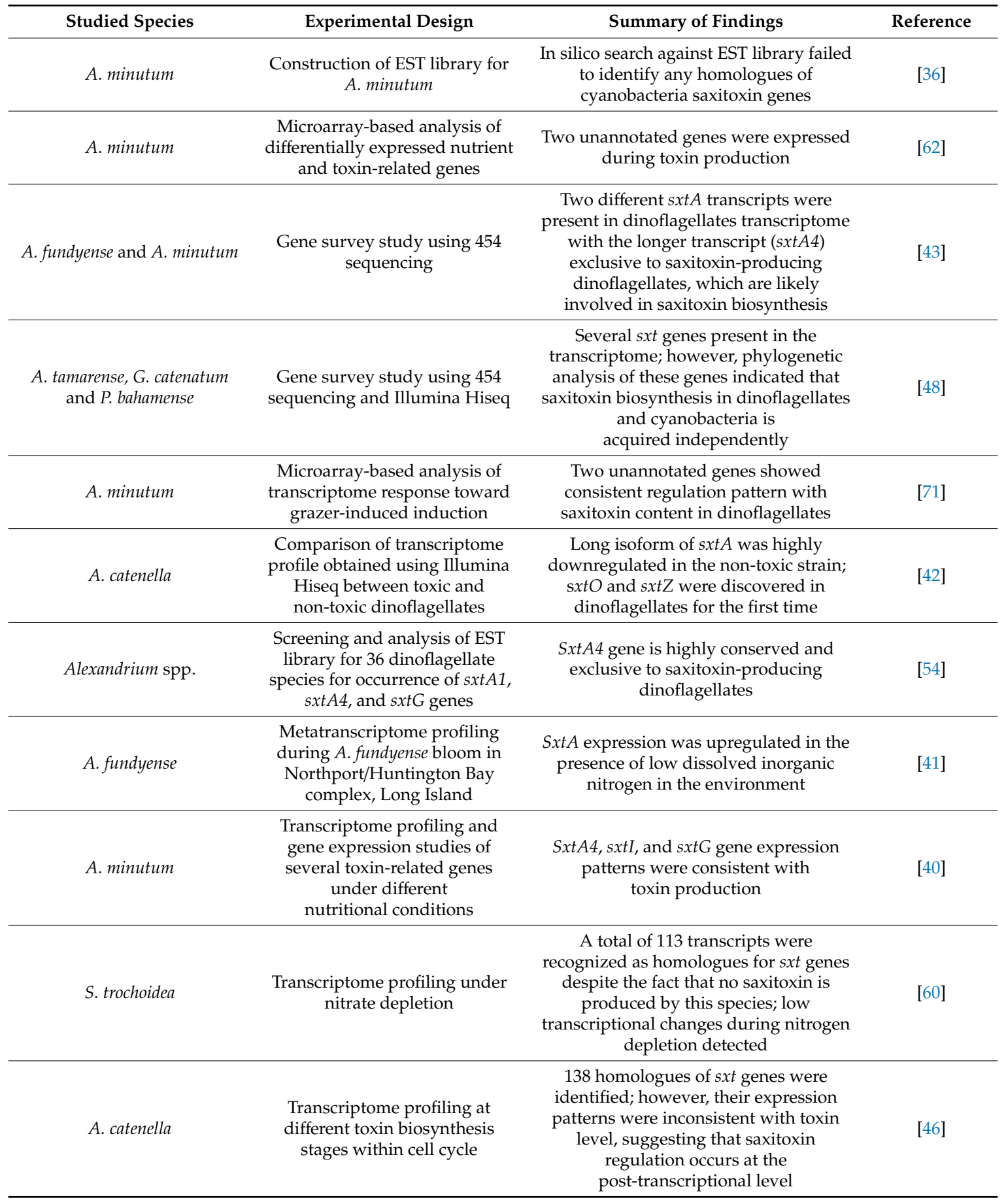

\section{Translational Control in Dinoflagellates and Its Implication on Saxitoxin Biosynthesis}

As previously mentioned, the changes in dinoflagellate gene expression were widely studied via several methods of transcriptomics approaches, such as microarrays and high-throughput RNA-sequencing. Limited transcriptional regulation in the dinoflagellates indicated that saxitoxin biosynthesis might be regulated at the translational level. Moreover, the discovery of a unique spliced leader sequence in dinoflagellate transcripts [72,73] suggested that most dinoflagellate genes are regulated at the post-transcriptional level as in some eukaryotes using a trans-splicing mechanism [74,75]. Regulation of saxitoxin biosynthesis at the post-transcriptional level via 
trans-splicing is additionally bolstered by sequence analysis of $s x t A 4$ and $s x t G$ transcripts that demonstrated the presence of a dinoflagellate spliced leader sequence in these genes $[43,44]$. Additionally, apart from the coding RNA transcripts in dinoflagellates, there are many non-coding RNA transcripts in dinoflagellates, e.g., microRNA (miRNA) [76-80]. These miRNAs were observed to post-transcriptionally direct the expression of several genes associated with different biological processes in dinoflagellates $[79,80]$. Given their potential role in gene regulation, the significance of miRNAs in regulating saxitoxin biosynthesis cannot be ignored, as several miRNAs were documented in saxitoxin-producing dinoflagellates $[77,78]$. In most eukaryotes, the protein translational mechanism begins with eukaryotic translation initiation factor 4E (eIF4E) through its interaction with the $5^{\prime}$-cap structure of mRNA [81]. Abundance and activities of protein elF4E often become the target for translational control, as seen in the phosphorylation of protein elF4E that regulates the circadian protein expression [82]. Recent discovery of an extensive transcript encoding the protein elF4E family in dinoflagellates provides additional evidence for substantial translational control in dinoflagellates [83].

More reports for translational control in dinoflagellates were found (Table 4), leading researchers to conclude that the expression of $s x t$ genes in dinoflagellates is controlled at the post-transcriptional or post-translational level owing to the inconsistent expression level at the transcript level documented by previous studies [46,49] and the presence of a dinoflagellate splice-leader sequence in at least two core genes for saxitoxin biosynthesis [43,44]. However, as we are still traversing in the unknown genetic territory, gene expression at the transcript level in dinoflagellates cannot be completely overlooked. Although limited, several studies documented effective regulation of dinoflagellate genes at the transcript level [32].

Table 4. Reports on translational control in dinoflagellates.

\begin{tabular}{ll}
\hline \multicolumn{1}{c}{ Findings } & Reference \\
\hline $\begin{array}{l}\text { Enzyme in the TCA cycle exhibited circadian changes in accordance with protein } \\
\text { abundance, whereas its messenger RNA (mRNA) level remained constant }\end{array}$ & [84] \\
throughout the cycle & [72,73] \\
\hline $\begin{array}{l}\text { Presence of unique splice leader at 5' of dinoflagellates mRNA might provide } \\
\text { translational regulation in dinoflagellates via trans-splicing }\end{array}$ & [85] \\
\hline $\begin{array}{l}\text { Expression of conserved S-phase genes in Karenia brevis remains unchanged } \\
\text { throughout cell cycle, but other protein expression level was observed }\end{array}$ & [43,44] \\
\hline $\begin{array}{l}\text { Presence of dinoflagellate spliced leader sequence at 5' of sxtA and sxtG genes } \\
\text { might indicate that saxitoxin biosynthesis is regulated at the translational level }\end{array}$ & [86] \\
\hline $\begin{array}{l}\text { Daily circadian system in dinoflagellate Lingulodinium showed lack of regulation at } \\
\text { the transcript level using RNA-sequencing approach, suggesting the involvement }\end{array}$ & \\
of translational or post-translational control of this system & [76-80] \\
\hline $\begin{array}{l}\text { Identification of microRNAs (miRNAs) in several species of dinoflagellates, } \\
\text { including saxitoxin-producing dinoflagellates, indicates regulation of several genes }\end{array}$ & \\
$\begin{array}{l}\text { in dinoflagellates at post-transcriptional level via a small RNA gene } \\
\text { silencing mechanism }\end{array}$ & [87] \\
\hline $\begin{array}{l}\text { Characterization of extensive transcript encoding protein elF4E family } \\
\text { in dinoflagellates }\end{array}$ & \\
\hline $\begin{array}{l}\text { Genome sequence of Symbiodinium kawagutii revealed substantial translational } \\
\text { control by miRNA in biological processes involving carbohydrate metabolism, } \\
\text { transcription regulation, and biosynthesis of amino acids and antibiotics }\end{array}$ & [79] \\
\hline Poor correlation between protein and mRNA level in dinoflagellate Lingulodinium & \\
\hline
\end{tabular}

\section{Proteomics Insight into Saxitoxin Biosynthesis}

Compared to RNA levels, protein abundance measurements are believed to be more closely correlated to catalytic capability and phenotypic observation of a cell [88]. The proteomics approach also 
enables researchers to discover biomarkers indicative of cell status, including toxicity. Thus, the study of proteins appears to be promising in facilitating the establishment of a molecular mechanism behind the regulation and biosynthesis of saxitoxin in dinoflagellates at the translational level. The technology and informatics advancement of the omics age enables researchers to examine hundreds to thousands of proteins simultaneously either via traditional 2-DE gel-based approach (two-dimensional gel electrophoresis), 2D DIGE (difference gel electrophoresis), label-free high-throughput shotgun liquid chromatography-tandem mass spectrometry (LC-MS/MS), or chemically labeled LC-MS/MS such as tandem mass tags (TMT) or isobaric tags for relative and absolute quantification (iTRAQ) [3,89,90].

Early studies on saxitoxin-producing dinoflagellates proteome focused on identifying candidate proteins that may function as biomarkers for its toxicity [91]. Combination of computational analysis on 2-DE gel combined with MALDI-TOF MS detection and N-terminal amino-acid sequencing revealed a candidate protein of T1, which showed a high correlation with toxicity in several strains of $A$. tamarense and A. minutum [91,92]. However, the role of this protein was unascertained, and further functional analysis is needed to determine the role of T1 protein in the saxitoxin biosynthesis. In another finding, polyketide synthase, histidine kinase, and chaperon-like proteins encoded by $s x t A, s x t Z$, and $s x t E$, respectively, were downregulated in the non-toxic strain of $A$. catenella, indicating the direct involvement of these proteins in saxitoxin biosynthesis. The upregulation of dihydrolipoamide succinyltransferase protein and succinyl-CoA synthetase subunit beta might reduce the flow of succinate, which is an important precursor for saxitoxin biosynthesis, thus resulting in lower toxin production [93]. Furthermore, nine putative proteins in saxitoxin biosynthesis (methionine $S$-adenosyltransferase, chloroplast ferredoxin-NADP ${ }^{+}$reductase, S-adenosyl homocysteinase, adenosylhomocysteinase, ornithine carbamoyltransferase, inorganic pyrophosphatase, sulfotransferase, alcohol dehydrogenase, and arginine deiminase) were identified in the proteome of saxitoxin-producing $A$. catenella, and their expression patterns throughout the different toxin biosynthesis stages showed a complex interaction network, proposing that these proteins might contribute to saxitoxin biosynthesis in a mutually promotive way [94] (Figure 3). Together, these results further suggest that saxitoxin biosynthesis in dinoflagellates is regulated at the translational level.

Differentially expressed protein analysis from saxitoxin-producing A. catenella and its non-toxic mutant, which lost the ability to form toxin during routine culture maintenance, showed suppression of several biological processes of amino-acid biosynthesis, fatty-acid biosynthesis, carbohydrate metabolism, photosynthesis, and bioluminescence, as well as their enhancement in the non-toxic mutant proteome $[93,95]$. These studies outlined that the elevated photosynthesis rate in the non-toxic mutant of $A$. catenella might contribute to its higher growth rate compared to its toxic counterpart. In another investigation, the proteomics analysis of mutated saxitoxin-producing $A$. catenella exposed to a cell-cycle inhibitor colchicine revealed the upregulation of several proteins involved in photosynthesis and carotenoid biosynthesis during the arrested toxin production stage, indicating the channeling of nitrogen compounds originally allocated for saxitoxin biosynthesis toward the synthesis of carotenoid and nitrogenous chlorophyll [96]. However, these claims can be contended with a finding by Jiang et al. [97] of several photosynthesis-related proteins having enhanced expression during the highly toxic period of saxitoxin-producing $A$. tamarense, which can be reflected back to a study by Etheridge and Roesler [98] that was unable to find a significant correlation between photosynthesis rate and toxin production in the toxic A. fundyense. Thus, it is unclear whether the rate of photosynthesis and growth rate directly affect saxitoxin biosynthesis in dinoflagellates or if the observations were just the effects of random mutation as shown in the case of the non-toxic mutant of $A$. catenella. The loss of toxicity in the $A$. lusitanicum strain even seems to be associated with a reduced growth rate, while comparable growth rates were observed between saxitoxin-producing $A$. tamarense and its non-toxic mutant $[99,100]$. Since the exact mutation localization in the genomic sequence of these strains is yet to be determined, and the fitness cost and tradeoffs between toxin biosynthesis and cell development of dinoflagellates are inadequately understood, differentially expressed proteins between these strains must be interpreted carefully. 

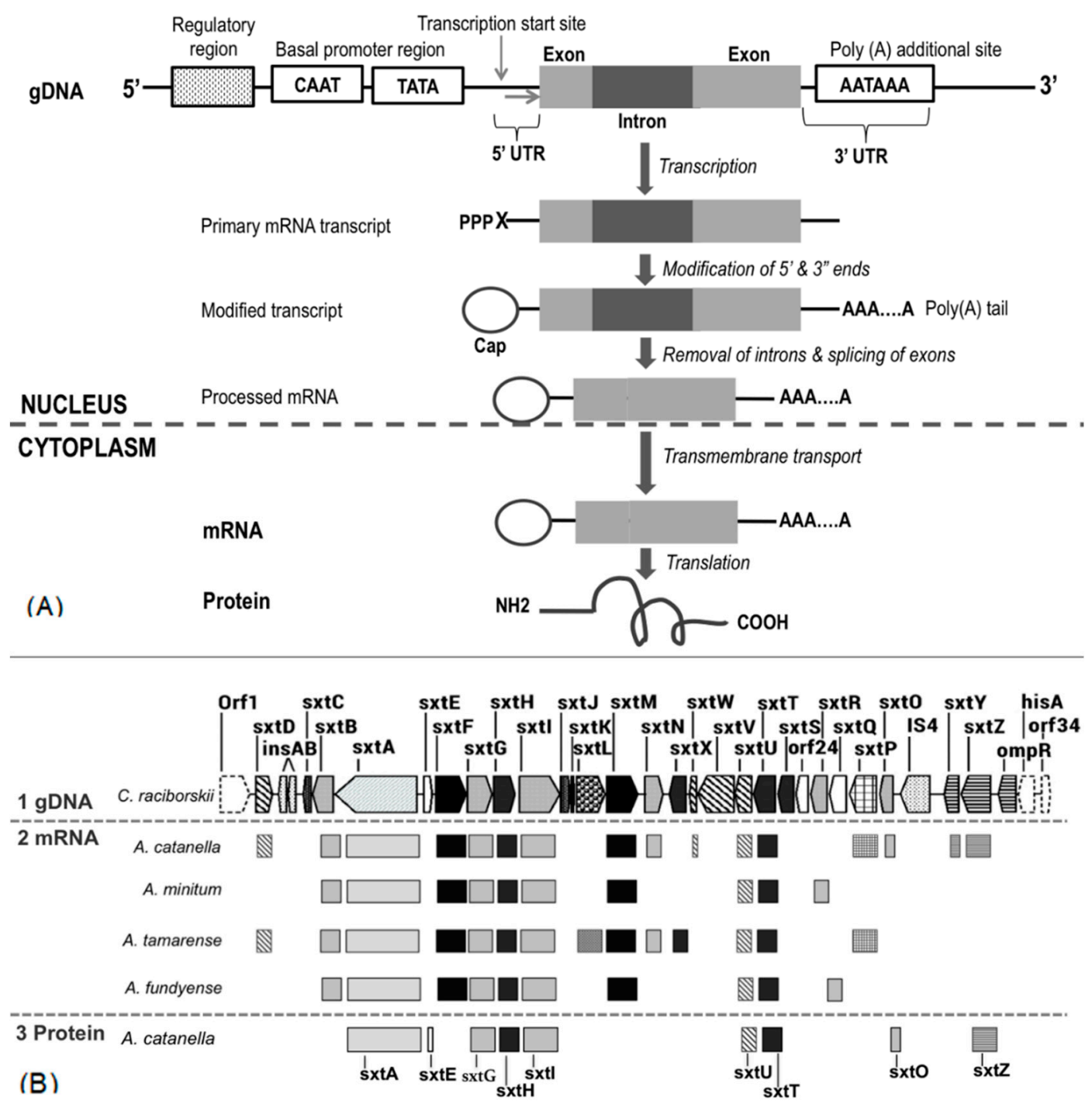

Figure 3. (A) Central dogma of molecular biology describing the flow of genetic information from a double-stranded genomic DNA template to post-translationally modified proteins. In the nucleus, the double-stranded DNA template is transcribed into a single-stranded pre-messenger RNA (mRNA), which is further processed through steps of modification of the $5^{\prime}$ and $3^{\prime}$ ends, polyadenylation, removal of introns, and splicing of exons. The mature mRNA is exported to the cytoplasm for translation to an amino-acid sequence, which is folded and/or post-translationally modified and subcellularly localized as a functional protein. (B) Information of $s x t$ molecules at the level of genomic DNA (gDNA), mRNA and protein. To date, the sxt gene cluster was successfully identified only in cyanobacteria species [28]. However, through transcriptomic analysis, several numbers of expressed mRNA were detected from several dinoflagellate species, as described in Table 2. Based on proteomic analysis, nine proteins encoded by sxt genes of $A$. catanella were identified as described in Section 5.

\section{Metabolomics within the Context of Saxitoxin Biosynthesis: An Unexplored Approach?}

Our present comprehension is yet to pinpoint the definite cause of these adjustments in saxitoxin biosynthesis, i.e., whether it is activated by changes in cellular metabolism, a consequence of pleiotropic alteration, or adaptation in the ecological condition. It is postulated that these changes may exert some effect on the central metabolism of dinoflagellates that then stimulates important precursor(s) for secondary metabolite biosynthesis as observed in other organisms, for example, plants, fungi, and marine diatoms [101-103]. In the hopes of linking the genotype to phenotype, metabolomics offers several advantages of unbiased snapshots of biochemical status, i.e., a reflection of the happenings 
at a functional level [104,105]. While metabolism was discussed since more than 700 years ago, "metabolomics" was first coined in 2001 and is considered the most recent component of the omics field, focusing on a snapshot measurement of small molecules or metabolites ( $<1500 \mathrm{Da})$ in a biological system under a given set of conditions [106-108]. The status of a metabolome as the ultimate end product of cellular regulatory processes gives researchers the opportunity to detect changes that arise from physiological or environmental events over shorter time scales, in view of the fact that the level of metabolite changes are believed to be highly correlated with organism phenotype [105,109]. In this sense, it is also important to note that metabolomics is more sensitive to time than the other omics [110]. The constantly evolving and yet subtle changes in a living system are measured by metabolomics, an approach that is appropriately viewed as "genetic information in motion" [111]. The utilization of metabolomics as a discovery platform permitted the elucidation of the polyketide-like synthase and the resulting $\alpha$-amino ketones the saxitoxin biosynthesis [112]. Another targeted assessment of the saxitoxin biosynthetic pathway was conducted using a nitrogen isotope tracer of sodium nitrate as a substrate to investigate nitrogen incorporation into the precursor, the biosynthetic intermediates, and the saxitoxin analogues in both toxin- and non-toxin-producing dinoflagellate species of $A$. catenella, Alexandrium insuetum, Prorocentrum triestinum, and G. catenatum [113]. The study supported the proposed biosynthetic pathway in Figure 2, and the quantitation of labeled and non-labeled arginine, saxitoxin biosynthetic intermediates, and the main saxitoxin analogues revealed the pool size of the amino acids and important metabolites that could provide information on the variability of toxin production under varying nutrient status.

It is anticipated that numerous exogenous signaling metabolites with plausible influence on saxitoxin production in dinoflagellates are to be detected and measured by means of metabolomics $[114,115]$. There are currently a limited number of reports that can be found on the external chemical cues for saxitoxin production in dinoflagellates. A. minutum boosted a multifold of its saxitoxin production, ensuing the prompts from copepodamides released by predatory zooplankton Centropages typicus, even though the zooplankton itself is resistant to saxitoxin toxicity [116]. These copepodamides are polar lipids which were also found to trigger higher poison output in domoic acid-producing diatoms as a defense mechanism against the herbivorous copepods [117]. The alteration or substitution of local microbial community was demonstrated to cause noteworthy changes in saxitoxin production by the athecate dinoflagellate G. catenatum [118]. This outcome is in agreement with the discovery of a later investigation, in which a few groups of bacteria were found to be present consistently among several strains of $A$. ostenfeldii, A. minutum, and A. tamarense [119]. The fascinating coexistence of dinoflagellates and bacteria in their phycosphere even led to the formulation of theories of saxitoxin biosynthesis by symbiotic bacteria living within the dinoflagellates. However, this notion was rejected when the structure of $s x t$ gene transcripts was represented, avowing that these genes are encoded in the genomes of dinoflagellates, and symbiont microbes may possibly assume an external chore in regulating saxitoxin production $[43,44]$. The precise physiological and biochemical impacts of these bacteria on dinoflagellates, as well as their ability to produce any signaling metabolites as a part of complex nutrient or deterrent exchange to affect the regulation of saxitoxin production, warrant a thorough analysis as attempted by Wang et al. [120] with the co-culture set-up for Dinoroseobacter shibae and Prorocentrum minimum but conjoined with metabolomics. Alongside the lethal saxitoxins of purine alkaloids, dinoflagellates also produce other toxins of spirolides, macrolides, and cyclic polyethers, for which definitive roles are still incognito to researchers. The arduous molecular characterization of their biosynthetic pathways can only be effectively uncovered with biochemical information [121].

\section{Future Directions and Conclusions}

The examination of dinoflagellate genomes is limited to known genes identified utilizing random approaches [122-125] with the exception of several high-quality draft genomes from the genus Symbiodinium $[79,126,127]$. While these works contributed important information in many aspects, the large and complex genome structure of dinoflagellates, especially in the view of the molecular 
mechanism for saxitoxin biosynthesis, is still uncracked. With the high gene copy number genome characteristic, copy number variation (CNV) emerged as another noteworthy source for phenotypic diversity within organism populations, as displayed in alveolate Plasmodium falciparum populations which share several similar genomic architectures with dinoflagellates [128]. Considered significant for adaptive evolution, CNV between dinoflagellate saxitoxin genes can be more confidently asserted together with its role, whether for adaptation or other responses, with the availability of genome sequence. In saxitoxin-producing cyanobacteria, the genes encoding saxitoxin biosynthesis are adjacent to each other in their genome as a biosynthetic gene cluster (BGC) $[28,30]$. However, sxt genes in dinoflagellates may or may not occur in a cluster. To date, several gene clusters were described in dinoflagellates including small nuclear RNA (snRNA), a hybrid NRPS-PKS, and mycosporine-like amino acid (MAA) gene clusters $[126,129,130]$. With the advancement of third-generation sequencing, such as single-molecule real-time (SMRT) sequencing by Pacific Biosystems (PacBio) and nanopore sequencing by Oxford Nanopore Techniques (ONT), challenges in sequencing large genomes to some extent will be overcome $[131,132]$. By utilizing long reads, third-generation sequencing lessens the burden for large genome assembly, allowing significant improvements of genome assemblies in repetitive regions via an overlap-layout-consensus approach [133]. We believe that the whole-genome sequence of saxitoxin-producing dinoflagellates is on the horizon, allowing the prediction of all genes, as well as microRNA and non-coding RNA, and revealing the architecture of the genome arrangement and its genomic landscape of many other genetic features.

Saxitoxin biosynthesis regulation is indeed a complex process, controlled by several environmental cues that are yet to be defined. At this point in time, omics-based studies in dinoflagellates focusing on saxitoxin biosynthesis are still sporadic and far from coming to a concrete closure. As the aquatic ecosystem is a continuum, the occurrence of saxitoxin-producing species will continue to expand geographically. This overwhelming situation combined with an unexplored genome might well be tackled with a bona fide integrated omics approach, in which the specimens are prepared and analyzed cohesively up to the data interpretation. Instead of combining layers of information from each of the omics carried out separately, integrated protocols of biomolecule extraction allow better correlation and cost efficiency from expending the same starting material [134]. Data analysis from this same set of specimens can then be analyzed in an algorithm, e.g., multivariate correlation, network analysis, and Granger causality, which allows many-to-many association, thereby interpreting the omics as a whole entity $[135,136]$. The ongoing development of these cutting-edge omics technologies and improvements in omics data mining will likely expand the omics-based studies in dinoflagellates in the near future, especially in decoding the saxitoxin biosynthesis enigma.

Author Contributions: M.A.A. and N.I.T. drafted the manuscript. N.Y.M.Y., F.K.S., A.A., G.U., and H.B. edited and added valuable insights to the manuscript. All authors read and approved the final manuscript.

Funding: This research was funded by the Malaysia Ministry of Education under the research grant FRGS/1/2019/STG05/UKM/02/6.

Acknowledgments: The authors would like to thank Fabrizio Alberti (Warwick University, UK) for his constructive comments on the manuscript.

Conflicts of Interest: The authors declare no conflict of interest.

\section{References}

1. Wiese, M.; D’agostino, P.M.; Mihali, T.K.; Moffitt, M.C.; Neilan, B.A. Neurotoxic alkaloids: Saxitoxin and its analogs. Mar. Drugs 2010, 8, 2185-2211. [CrossRef]

2. Cusick, K.; Sayler, G. An overview on the marine neurotoxin, saxitoxin: Genetics, molecular targets, methods of detection and ecological functions. Mar. Drugs 2013, 11, 991-1018. [CrossRef]

3. Wang, D.Z.; Zhang, S.F.; Zhang, Y.; Lin, L. Paralytic shellfish toxin biosynthesis in cyanobacteria and dinoflagellates: A molecular overview. J. Proteom. 2016, 135, 132-140. [CrossRef] 
4. Schantz, E.J.; Mold, J.D.; Stanger, D.W.; Shavel, J.; Riel, F.J.; Bowden, J.P.; Sommer, H. Paralytic shellfish poison. VI. A procedure for the isolation and purification of the poison from toxic clam and mussel tissues. J. Am. Chem. Soc. 1957, 79, 5230-5235. [CrossRef]

5. Walker, J.R.; Merit, J.E.; Thomas-Tran, R.; Tang, D.T.; Du Bois, J. Divergent Synthesis of Natural Derivatives of (+)-Saxitoxin Including 11-Saxitoxinethanoic Acid. Angew. Chem. Int. Ed. 2019, 58, 1689-1693. [CrossRef]

6. Orr, R.; Stüken, A.; Murray, S.; Jakobsen, K. Evolution and distribution of saxitoxin biosynthesis in dinoflagellates. Mar. Drugs 2013, 11, 2814-2828. [CrossRef]

7. Ciminiello, P.; Fattorusso, E.; Forino, M.; Montresor, M. Saxitoxin and neosaxitoxin as toxic principles of Alexandrium andersoni (Dinophyceae) from the Gulf of Naples, Italy. Toxicon 2000, 38, 1871-1877. [CrossRef]

8. Krock, B.; Seguel, C.G.; Cembella, A.D. Toxin profile of Alexandrium catenella from the Chilean coast as determined by liquid chromatography with fluorescence detection and liquid chromatography coupled with tandem mass spectrometry. Harmful Algae 2007, 6, 734-744. [CrossRef]

9. Poulton, N.J.; Keafer, B.A.; Anderson, D.M. Toxin variability in natural populations of Alexandrium fundyense in Casco Bay, Maine-Evidence of nitrogen limitation. Deep Sea Res. PT II 2005, 52, 2501-2521. [CrossRef]

10. Ichimi, K.; Suzuki, T.; Ito, A. Variety of PSP toxin profiles in various culture strains of Alexandrium tamarense and change of toxin profile in natural A. tamarense population. J. Exp. Mar. Biol. Ecol. 2002, 273, 51-60. [CrossRef]

11. Usup, G.; Kulis, D.M.; Anderson, D.M. Growth and toxin production of the toxic dinoflagellate Pyrodinium bahamense var. compressum in laboratory cultures. Nat. Toxins 1994, 2, 254-262. [CrossRef]

12. Gárate-Lizárraga, I.; Bustillos-Guzmán, J.J.; Morquecho, L.; Band-Schmidt, C.J.; Alonso-Rodríguez, R.; Erler, K.; Luckas, B.; Reyes-Salinas, A.; Góngora-González, D.T. Comparative paralytic shellfish toxin profiles in the strains of Gymnodinium catenatum Graham from the Gulf of California, Mexico. Mar. Pollut. Bull. 2005, 50, 211-217. [CrossRef] [PubMed]

13. Pitcher, G.C.; Cembella, A.D.; Joyce, L.B.; Larsen, J.; Probyn, T.A.; Ruiz Sebastián, C. The dinoflagellate Alexandrium minutum in Cape Town harbour (South Africa): Bloom characteristics, phylogenetic analysis and toxin composition. Harmful Algae 2007, 6, 823-836. [CrossRef]

14. Sebastián, C.R.; Etheridge, S.M.; Cook, P.A.; O’Ryan, C.; Pitcher, G.C. Phylogenetic analysis of toxic Alexandrium (Dinophyceae) isolates from South Africa: Implications for the global phylogeography of the Alexandrium tamarense species complex. Phycologia 2005, 44, 49-60. [CrossRef]

15. Hansen, P.J.; Cembella, A.D.; Moestrup, Ø. The marine dinoflagellate Alexandrium ostenfeldii: Paralytic shellfish toxin concentration, composition and toxicity to a tintinnid cilliate. J. Phycol. 1992, 28, 597-603. [CrossRef]

16. Holmes, M.J.; Bolch, C.J.S.; Green, D.H.; Cembella, A.D.; Teo, S.L.M. Singapore isolates of the dinoflagellate Gymnodinium catenatum (Dinophyceae) produce a unique profile of paralytic shellfish poisoning toxins. J. Phycol. 2002, 38, 96-106. [CrossRef]

17. Jaime, E.; Gerdts, G.; Luckas, B. In vitro transformation of PSP toxins by different shellfish tissues. Harmful Algae 2007, 6, 308-316. [CrossRef]

18. Yu, R.; Hummert, C.; Luckas, B.; Qian, P.; Li, J.; Zhou, M. A modified HPLC method for analysis of PSP toxins in algae and shellfish from china. Chromatographia 1998, 48, 671-676. [CrossRef]

19. Vale, P. Metabolites of saxitoxin analogues in bivalves contaminated by Gymnodinium catenatum. Toxicon 2010, 55, 162-165. [CrossRef]

20. Cho, Y.; Tsuchiya, S.; Yoshioka, R.; Omura, T.; Konoki, K.; Oshima, Y.; Yotsu-Yamashita, M. The presence of $12 \beta$-deoxydecarbamoylsaxitoxin in the Japanese toxic dinoflagellate Alexandrium determined by simultaneous analysis for paralytic shellfish toxins using HILIC-LC-MS/MS. Harmful Algae 2015, 49, 58-67. [CrossRef]

21. Negri, A.; Stirling, D.; Quilliam, M.; Blackburn, S.; Bolch, C.; Burton, I.; Eaglesham, G.; Thomas, K.; Walter, J.; Willis, R. Three novel hydroxybenzoate saxitoxin analogues isolated from the dinoflagellate Gymnodinium catenatum. Chem. Res. Toxicol. 2003, 16, 1029-1033. [CrossRef]

22. Oshima, Y.; Sugino, K.; Itakura, H.; Hirota, M.; Yasumoto, T.; Grane'li, E.; Sundstrom, B.; Edler, L.; Anderson, D.M. Comparative studies on paralytic shellfish toxin profile of dinoflagellates and bivalves. In Toxic Marine Phytoplankton; Elsevier Science Publishing: New York, NY, USA, 1990; pp. 391-396. 
23. Mohana, N.C.; Rao, H.Y.; Rakshith, D.; Mithun, P.R.; Nuthan, B.R.; Satish, S. Omics based approach for biodiscovery of microbial natural products in antibiotic resistance era. J. Genet. Eng. Biotechnol. 2018, 16, 1-8. [CrossRef] [PubMed]

24. Palazzotto, E.; Weber, T. Omics and multi-omics approaches to study the biosynthesis of secondary metabolites in microorganisms. Curr. Opin. Microbiol. 2018, 45, 109-116. [CrossRef] [PubMed]

25. Zhang, W.; Li, F.; Nie, L. Integrating multiple 'omics' analysis for microbial biology: Application and methodologies. Microbiology 2010, 156, 287-301. [CrossRef] [PubMed]

26. Weckwerth, W.; Wenzel, K.; Fiehn, O. Process for the integrated extraction, identification and quantification of metabolites, proteins and RNA to reveal their co-regulation in biochemical networks. Proteomics 2004, 4, 78-83. [CrossRef]

27. Shimizu, Y.; Norte, M.; Hori, A.; Genenah, A.; Kobayashi, M. Biosynthesis of saxitoxin analogs: The unexpected pathway. J. Am. Chem. Soc. 1984, 106, 6433-6434. [CrossRef]

28. Kellmann, R.; Mihali, T.K.; Jeon, Y.J.; Pickford, R.; Pomati, F.; Neilan, B.A. Biosynthetic intermediate analysis and functional homology reveal a saxitoxin gene cluster in cyanobacteria. Appl. Environ. Microbiol. 2008, 74, 4044-4053. [CrossRef]

29. Mihali, T.K.; Kellmann, R.; Neilan, B.A. Characterisation of the paralytic shellfish toxin biosynthesis gene clusters in Anabaena circinalis AWQC131C and Aphanizomenon sp. NH-5. BMC Biochem. 2009, 10, 8. [CrossRef]

30. Mihali, T.K.; Carmichael, W.W.; Neilan, B.A. A putative gene cluster from a Lyngbya wollei bloom that encodes paralytic shellfish toxin biosynthesis. PLoS ONE 2011, 6, e14657. [CrossRef]

31. Moustafa, A.; Loram, J.E.; Hackett, J.D.; Anderson, D.M.; Plumley, F.G.; Bhattacharya, D. Origin of saxitoxin biosynthetic genes in cyanobacteria. PLoS ONE 2009, 4, e5758. [CrossRef]

32. Akbar, M.A.; Ahmad, A.; Usup, G.; Bunawan, H. Current Knowledge and Recent Advances in Marine Dinoflagellate Transcriptomic Research. J. Mar. Sci. Eng. 2018, 6, 13. [CrossRef]

33. Akbar, M.A.; Ahmad, A.; Usup, G.; Bunawan, H. RNA-Seq as an Emerging Tool for Marine Dinoflagellate Transcriptome Analysis: Process and Challenges. Processes 2018, 6, 5. [CrossRef]

34. Tsuchiya, S.; Cho, Y.; Konoki, K.; Nagasawa, K.; Oshima, Y.; Yotsu-Yamashita, M. Synthesis of a tricyclic bisguanidine compound structurally related to saxitoxin and its identification in paralytic shellfish toxin-producing microorganisms. Chem.: Eur. J 2015, 21, 7835-7840. [CrossRef]

35. Cho, Y.; Tsuchiya, S.; Yoshioka, R.; Omura, T.; Konoki, K.; Oshima, Y.; Yotsu-Yamashita, M. Column switching combined with hydrophilic interaction chromatography-tandem mass spectrometry for the analysis of saxitoxin analogues, and their biosynthetic intermediates in dinoflagellates. J. Chromatogr. A 2016, 1474, 109-120. [CrossRef]

36. Yang, I.; John, U.; Beszteri, S.; Glöckner, G.; Krock, B.; Goesmann, A.; Cembella, A.D. Comparative gene expression in toxic versus non-toxic strains of the marine dinoflagellate Alexandrium minutum. BMC Genom. 2010, 11, 248. [CrossRef]

37. Wang, Z.; Gerstein, M.; Snyder, M. RNA-Seq: A revolutionary tool for transcriptomics. Nat. Rev. Genet. 2009, 10, 57-63. [CrossRef]

38. Hii, K.S.; Lim, P.T.; Tan, T.H.; Leaw, C.P. Characterization of the saxitoxin biosynthetic starting gene, sxtA in the toxic dinoflagellate Alexandrium tamiyavanichii. In Proceedings of the 12th Symposium of the Malaysian Society of Applied Biology: Solutions to Global Challenges and Issues, Kuala Terengganu, Malaysia, 1-3 June 2012; pp. 196-202.

39. Le Gac, M.; Metegnier, G.; Chomérat, N.; Malestroit, P.; Quéré, J.; Bouchez, O.; Siano, R.; Destombe, C.; Guillou, L.; Chapelle, A. Evolutionary processes and cellular functions underlying divergence in Alexandrium minutum. Mol. Ecol. 2016, 25, 5129-5143. [CrossRef]

40. Hii, K.S.; Lim, P.T.; Kon, N.F.; Takata, Y.; Usup, G.; Leaw, C.P. Physiological and transcriptional responses to inorganic nutrition in a tropical Pacific strain of Alexandrium minutum: Implications for the saxitoxin genes and toxin production. Harmful Algae 2016, 56, 9-21. [CrossRef]

41. Zhuang, Y.; Zhang, H.; Hannick, L.; Lin, S. Metatranscriptome profiling reveals versatile N-nutrient utilization, $\mathrm{CO} 2$ limitation, oxidative stress, and active toxin production in an Alexandrium fundyense bloom. Harmful Algae. 2015, 42, 60-70. [CrossRef]

42. Zhang, Y.; Zhang, S.F.; Lin, L.; Wang, D.Z. Comparative transcriptome analysis of a toxin-producing dinoflagellate Alexandrium catenella and its non-toxic mutant. Mar. Drugs 2014, 12, 5698-5718. [CrossRef] 
43. Stüken, A.; Orr, R.J.S.; Kellmann, R.; Murray, S.A.; Neilan, B.A.; Jakobsen, K.S. Discovery of nuclear-encoded genes for the neurotoxin saxitoxin in dinoflagellates. PLoS ONE 2011, 6, e20096. [CrossRef] [PubMed]

44. Orr, R.J.; Stüken, A.; Murray, S.A.; Jakobsen, K.S. Evolutionary acquisition and loss of saxitoxin biosynthesis in dinoflagellates: The second "core" gene-sxtG. Appl. Environ. Microbiol. 2013, 79, 2128-2136. [CrossRef] [PubMed]

45. Wiese, M.; Murray, S.A.; Alvin, A.; Neilan, B.A. Gene expression and molecular evolution of sxtA4 in a saxitoxin producing dinoflagellate Alexandrium catenella. Toxicon 2014, 92, 102-112. [CrossRef] [PubMed]

46. Zhang, Y.; Zhang, S.F.; Lin, L.; Wang, D.Z. Whole transcriptomic analysis provides insights into molecular mechanisms for toxin biosynthesis in a toxic dinoflagellate Alexandrium catenella (ACHK-T). Toxins 2017, 9 , 213. [CrossRef] [PubMed]

47. Suikkanen, S.; Kremp, A.; Hautala, H.; Krock, B. Paralytic shellfish toxins or spirolides? The role of environmental and genetic factors in toxin production of the Alexandrium ostenfeldii complex. Harmful Algae 2013, 26, 52-59. [CrossRef]

48. Hackett, J.D.; Wisecaver, J.H.; Brosnahan, M.L.; Kulis, D.M.; Anderson, D.M.; Bhattacharya, D.; Gerald Plumley, F.; Erdner, D.L. Evolution of saxitoxin synthesis in cyanobacteria and dinoflagellates. Mol. Biol. Evol. 2012, 30, 70-78. [CrossRef] [PubMed]

49. Perini, F.; Galluzzi, L.; Dell'Aversano, C.; Iacovo, E.D.; Tartaglione, L.; Ricci, F.; Forino, M.; Ciminiello, P.; Penna, A. SxtA and sxtG gene expression and toxin production in the Mediterranean Alexandrium minutum (Dinophyceae). Mar. Drugs 2014, 12, 5258-5276. [CrossRef]

50. Stüken, A.; Riobó, P.; Franco, J.; Jakobsen, K.S.; Guillou, L.; Figueroa, R.I. Paralytic shellfish toxin content is related to genomic sxtA4 copy number in Alexandrium minutum strains. Front. Microbiol. 2015, 6, 404. [CrossRef]

51. Savela, H.; Harju, K.; Spoof, L.; Lindehoff, E.; Meriluoto, J.; Vehniäinen, M.; Kremp, A. Quantity of the dinoflagellate sxtA4 gene and cell density correlates with paralytic shellfish toxin production in Alexandrium ostenfeldii blooms. Harmful Algae 2016, 52, 1-10. [CrossRef]

52. Stüken, A.; Dittami, S.M.; Eikrem, W.; McNamee, S.; Campbell, K.; Jakobsen, K.S.; Edvardsen, B. Novel hydrolysis-probe based qPCR assay to detect saxitoxin transcripts of dinoflagellates in environmental samples. Harmful Algae 2013, 28, 108-117. [CrossRef]

53. Murray, S.A.; Wiese, M.; Stüken, A.; Brett, S.; Kellmann, R.; Hallegraeff, G.; Neilan, B.A. A quantitative molecular assay based on the gene sxtA to identify saxitoxin-producing harmful algal blooms in marine waters. Appl. Environ. Microbiol 2011. [CrossRef] [PubMed]

54. Murray, S.A.; Diwan, R.; Orr, R.J.; Kohli, G.S.; John, U. Gene duplication, loss and selection in the evolution of saxitoxin biosynthesis in alveolates. Mol. Phylogenet. Evol. 2015, 92, 165-180. [CrossRef] [PubMed]

55. John, U.; Fensome, R.A.; Medlin, L.K. The application of a molecular clock based on molecular sequences and the fossil record to explain biogeographic distributions within the Alexandrium tamarense "species complex" (Dinophyceae). Mol. Biol. Evol. 2003, 20, 1015-1027. [CrossRef] [PubMed]

56. Song, B.; Chen, S.; Chen, W. Dinoflagellates, a unique lineage for retrogene research. Front. Microbiol. 2018, 9 , 1556. [CrossRef]

57. Kaessmann, H.; Vinckenbosch, N.; Long, M. RNA-based gene duplication: Mechanistic and evolutionary insights. Nat. Rev. Genet. 2009, 10, 19-31. [CrossRef]

58. Song, B.; Morse, D.; Song, Y.; Fu, Y.; Lin, X.; Wang, W.; Lin, S. Comparative genomics reveals two major bouts of gene retroposition coinciding with crucial periods of Symbiodinium evolution. Genome Biol. Evol. 2017, 9 , 2037-2047. [CrossRef]

59. Reen, F.J.; Romano, S.; Dobson, A.D.; O'Gara, F. The sound of silence: Activating silent biosynthetic gene clusters in marine microorganisms. Mar. Drugs 2015, 13, 4754-4783. [CrossRef]

60. Cooper, J.T.; Sinclair, G.A.; Wawrik, B. Transcriptome analysis of Scrippsiella trochoidea CCMP 3099 reveals physiological changes related to nitrate depletion. Front. Microbiol. 2016, 7, 639. [CrossRef]

61. Biecker, A.L.; Liu, X.; Thorson, J.S.; Yang, Z.; Van Lanen, S.G. Biosynthetic and synthetic strategies for assembling capuramycin-type antituberculosis antibiotics. Molecules 2019, 24, 433. [CrossRef]

62. Yang, I.; Beszteri, S.; Tillmann, U.; Cembella, A.; John, U. Growth-and nutrient-dependent gene expression in the toxigenic marine dinoflagellate Alexandrium minutum. Harmful Algae 2011, 12, 55-69. [CrossRef] 
63. Han, M.; Lee, H.; Anderson, D.M.; Kim, B. Paralytic shellfish toxin production by the dinoflagellate Alexandrium pacificum (Chinhae Bay, Korea) in axenic, nutrient-limited chemostat cultures and nutrient-enriched batch cultures. Mar. Pollut. Bull. 2016, 104, 34-43. [CrossRef] [PubMed]

64. Erdner, D.L.; Anderson, D.M. Global transcriptional profiling of the toxic dinoflagellate Alexandrium fundyense using massively parallel signature sequencing. BMC Genom. 2006, 7, 88. [CrossRef] [PubMed]

65. Moustafa, A.; Evans, A.N.; Kulis, D.M.; Hackett, J.D.; Erdner, D.L.; Anderson, D.M.; Bhattacharya, D. Transcriptome profiling of a toxic dinoflagellate reveals a gene-rich protist and a potential impact on gene expression due to bacterial presence. PLoS ONE 2010, 5, e9688. [CrossRef] [PubMed]

66. Lauritano, C.; De Luca, D.; Ferrarini, A.; Avanzato, C.; Minio, A.; Esposito, F.; Ianora, A. De novo transcriptome of the cosmopolitan dinoflagellate Amphidinium carterae to identify enzymes with biotechnological potential. Sci. Rep. 2017, 7, 11701. [CrossRef]

67. Lin, S. Genomic understanding of dinoflagellates. Res. Microbiol. 2011, 16, 551-569. [CrossRef]

68. Gacek-Matthews, A.; Berger, H.; Sasaki, T.; Wittstein, K.; Gruber, C.; Lewis, Z.A.; Strauss, J. KdmB, a Jumonji histone $\mathrm{H} 3$ demethylase, regulates genome-wide $\mathrm{H} 3 \mathrm{~K} 4$ trimethylation and is required for normal induction of secondary metabolism in Aspergillus nidulans. PLoS Genet. 2016, 12, e1006222. [CrossRef]

69. Pidroni, A.; Faber, B.; Brosch, G.; Bauer, I.; Graessle, S. A Class 1 Histone Deacetylase as Major Regulator of Secondary Metabolite Production in Aspergillus nidulans. Front. Microbiol. 2018, 9, 2212. [CrossRef]

70. Roy, S.; Morse, D. A full suite of histone and histone modifying genes are transcribed in the dinoflagellate Lingulodinium. PLoS ONE 2012, 7, e34340. [CrossRef]

71. Yang, I.; Selander, E.; Pavia, H.; John, U. Grazer-induced toxin formation in dinoflagellates: A transcriptomic model study. Eur. J. Phycol. 2011, 46, 66-73. [CrossRef]

72. Zhang, H.; Hou, Y.; Miranda, L.; Campbell, D.A.; Sturm, N.R.; Gaasterland, T.; Lin, S. Spliced leader RNA trans-splicing in dinoflagellates. Proc. Natl. Acad. Sci. USA 2007, 104, 4618-4623. [CrossRef]

73. Lidie, K.B.; Van Dolah, F.M. Spliced leader RNA-mediated trans-splicing in a dinoflagellate, Karenia brevis. J. Eukaryot Microbiol. 2007, 54, 427-435. [CrossRef] [PubMed]

74. Danks, G.B.; Raasholm, M.; Campsteijn, C.; Long, A.M.; Manak, J.R.; Lenhard, B.; Thompson, E.M. Trans-splicing and operons in metazoans: Translational control in maternally regulated development and recovery from growth arrest. Mol. Biol. Evol. 2015, 32, 585-599. [CrossRef] [PubMed]

75. Bitar, M.; Boroni, M.; Macedo, A.M.; Machado, C.R.; Franco, G.R. The spliced leader trans-splicing mechanism in different organisms: Molecular details and possible biological roles. Front. Genet. 2013, 4, 199. [CrossRef] [PubMed]

76. Baumgarten, S.; Bayer, T.; Aranda, M.; Liew, Y.J.; Carr, A.; Micklem, G.; Voolstra, C.R. Integrating microRNA and mRNA expression profiling in Symbiodinium microadriaticum, a dinoflagellate symbiont of reef-building corals. BMC Genom. 2013, 14, 704. [CrossRef] [PubMed]

77. Gao, D.; Qiu, L.; Hou, Z.; Zhang, Q.; Wu, J.; Gao, Q.; Song, L. Computational identification of microRNAs from the expressed sequence tags of toxic dinoflagellate Alexandrium tamarense. Evol. Bioinform. 2013, 9 , 479-485. [CrossRef] [PubMed]

78. Geng, H.; Sui, Z.; Zhang, S.; Du, Q.; Ren, Y.; Liu, Y.; Kong, F.; Zhong, J.; Ma, Q. Identification of microRNAs in the toxigenic Dinoflagellate Alexandrium catenella by high-throughput illumina sequencing and bioinformatic analysis. PLoS ONE 2015, 10, e0138709. [CrossRef] [PubMed]

79. Lin, S.; Cheng, S.; Song, B.; Zhong, X.; Lin, X.; Li, W.; Li, L.; Zhang, Y.; Zhang, H.; Ji, Z.; et al. The Symbiodinium kawagutii genome illuminates dinoflagellate gene expression and coral symbiosis. Science 2015, 350, 691-694. [CrossRef]

80. Shi, X.; Lin, X.; Li, L.; Li, M.; Palenik, B.; Lin, S. Transcriptomic and microRNAomic profiling reveals multi-faceted mechanisms to cope with phosphate stress in a dinoflagellate. ISME J. 2017, 11, 2209-2218. [CrossRef]

81. Jagus, R.; Bachvaroff, T.R.; Joshi, B.; Place, A.R. Diversity of eukaryotic translational initiation factor eIF4E in protists. Comp. Funct. Genom. 2012, 2012, 134839. [CrossRef]

82. Herdy, B.; Jaramillo, M.; Svitkin, Y.V.; Rosenfeld, A.B.; Kobayashi, M.; Walsh, D.; Alain, T.; Sean, P.; Robichaud, N.; Topisirovic, I.; et al. Translational control of the activation of transcription factor NF- $\mathrm{kB}$ and production of type I interferon by phosphorylation of the translation factor eIF4E. Nat. Immunol. 2012, 13, 543-550. [CrossRef] 
83. Jones, G.D.; Williams, E.P.; Place, A.R.; Jagus, R.; Bachvaroff, T.R. The alveolate translation initiation factor 4E family reveals a custom toolkit for translational control in core dinoflagellates. BMC Evol. Biol. 2015, 15, 14. [CrossRef] [PubMed]

84. Akimoto, H.; Kinumi, T.; Ohmiya, Y. Circadian rhythm of a TCA cycle enzyme is apparently regulated at the translational level in the dinoflagellate Lingulodinium polyedrum. J. Biol. Rhythm 2005, 20, 479-489. [CrossRef] [PubMed]

85. Brunelle, S.A.; Van Dolah, F.M. Post-transcriptional regulation of S-phase genes in the dinoflagellate, Karenia brevis. J. Eukaryot Microbiol. 2011, 58, 373-382. [CrossRef]

86. Roy, S.; Beauchemin, M.; Dagenais-Bellefeuille, S.; Letourneau, L.; Cappadocia, M.; Morse, D. The Lingulodinium circadian system lacks rhythmic changes in transcript abundance. BMC Biol. 2014, 12, 107. [CrossRef]

87. Tse, S.P.; Beauchemin, M.; Morse, D.; Lo, S.C. Refining Transcriptome Gene Catalogs by MS-Validation of Expressed Proteins. Proteomics 2018, 18, 1700271. [CrossRef]

88. Morse, D.; Sirius, P.K.; Lo, S.C. Exploring dinoflagellate biology with high-throughput proteomics. Harmful Algae 2018, 75, 16-26. [CrossRef]

89. Erdjument-Bromage, H.; Huang, F.K.; Neubert, T.A. Sample Preparation for Relative Quantitation of Proteins Using Tandem Mass Tags (TMT) and Mass Spectrometry (MS). Methods Mol. Biol. 2018, 1741, 135-149. [CrossRef]

90. Wang, D.Z.; Zhang, H.; Zhang, Y.; Zhang, S.F. Marine dinoflagellate proteomics: Current status and future perspectives. J. Proteom. 2014, 105, 121-132. [CrossRef]

91. Chan, L.L.; Sit, W.H.; Lam, P.K.S.; Hsieh, D.P.H.; Hodgkiss, I.J.; Wan, J.M.F.; Ho, A.Y.; Choi, N.M.; Wang, D.Z.; Dudgeon, D. Identification and characterization of a "biomarker of toxicity" from the proteome of the paralytic shellfish toxin-producing dinoflagellate Alexandrium tamarense (Dinophyceae). Proteomics 2006, 6, 654-666. [CrossRef]

92. Chan, L.L.; Hodgkiss, I.J.; Lam, P.K.S.; Wan, J.M.F.; Chou, H.N.; Lum, J.H.; Lo, M.G.; Mak, A.S.; Sit, W.H.; Lo, S.C. Use of two-dimensional gel electrophoresis to differentiate morphospecies of Alexandrium minutum, a paralytic shellfish poisoning toxin-producing dinoflagellate of harmful algal blooms. Proteomics 2005, 5, 1580-1593. [CrossRef]

93. Wang, D.Z.; Li, C.; Zhang, Y.; Wang, Y.Y.; He, Z.P.; Lin, L.; Hong, H.S. Quantitative proteomic analysis of differentially expressed proteins in the toxicity-lost mutant of Alexandrium catenella (Dinophyceae) in the exponential phase. J. Proteom. 2012, 75, 5564-5577. [CrossRef] [PubMed]

94. Wang, D.Z.; Gao, Y.; Lin, L.; Hong, H.S. Comparative proteomic analysis reveals proteins putatively involved in toxin biosynthesis in the marine dinoflagellate Alexandrium catenella. Mar. Drugs 2013, 11, $213-232$. [CrossRef] [PubMed]

95. Zhang, S.F.; Zhang, Y.; Xie, Z.X.; Zhang, H.; Lin, L.; Wang, D.Z. iTRAQ-based quantitative proteomic analysis of a toxigenic dinoflagellate Alexandrium catenella and its non-toxic mutant. Proteomics 2015, 15, 4041-4050. [CrossRef] [PubMed]

96. Zhang, S.F.; Zhang, Y.; Lin, L.; Wang, D.Z. iTRAQ-based quantitative proteomic analysis of a toxigenic dinoflagellate Alexandrium catenella and its non-toxigenic mutant exposed to a cell cycle inhibitor colchicine. Front. Microbiol. 2018, 9, 650. [CrossRef]

97. Jiang, X.W.; Wang, J.; Gao, Y.; Chan, L.L.; Lam, P.K.S.; Gu, J.D. Relationship of proteomic variation and toxin synthesis in the dinoflagellate Alexandrium tamarense CI01 under phosphorus and inorganic nitrogen limitation. Ecotoxicology 2015, 24, 1744-1753. [CrossRef]

98. Etheridge, S.M.; Roesler, C.S. Effects of temperature, irradiance, and salinity on photosynthesis, growth rates, total toxicity, and toxin composition for Alexandrium fundyense isolates from the Gulf of Maine and Bay of Fundy. Deep Sea Res. Pt II 2005, 52, 2491-2500. [CrossRef]

99. Cho, Y.; Hiramatsu, K.; Ogawa, M.; Omura, T.; Ishimaru, T.; Oshima, Y. Non-toxic and toxic subclones obtained from a toxic clonal culture of Alexandrium tamarense (Dinophyceae): Toxicity and molecular biological feature. Harmful Algae 2008, 7, 740-751. [CrossRef]

100. Martins, C.A.; Kulis, D.; Franca, S.; Anderson, D.M. The loss of PSP toxin production in a formerly toxic Alexandrium lusitanicum clone. Toxicon 2004, 43, 195-205. [CrossRef] 
101. Fritz, C.; Palacios-Rojas, N.; Feil, R.; Stitt, M. Regulation of secondary metabolism by the carbon-nitrogen status in tobacco: Nitrate inhibits large sectors of phenylpropanoid metabolism. Plant J. 2006, 46, 533-548. [CrossRef]

102. Twumasi-Boateng, K.; Yu, Y.; Chen, D.; Gravelat, F.N.; Nierman, W.C.; Sheppard, D.C. Transcriptional profiling identifies a role for BrlA in the response to nitrogen depletion and for StuA in the regulation of secondary metabolite clusters in Aspergillus fumigatus. Eukaryot. Cell 2009, 8, 104-115. [CrossRef]

103. Allen, A.E.; Vardi, A.; Bowler, C. An ecological and evolutionary context for integrated nitrogen metabolism and related signaling pathways in marine diatoms. Curr. Opin. Plant Biol. 2006, 9, 264-273. [CrossRef]

104. Goodacre, R.; Vaidyanathan, S.; Dunn, W.B.; Harrigan, G.G.; Kell, D.B. Metabolomics by numbers: Acquiring and understanding global metabolite data. Trends Biotechnol. 2004, 22, 245-252. [CrossRef]

105. Stringer, K.A.; McKay, R.T.; Karnovsky, A.; Quémerais, B.; Lacy, P. Metabolomics and its application to acute lung diseases. Front. Immunol. 2016, 7, 44. [CrossRef]

106. van der Greef, J.; van Wietmarschen, H.; van Ommen, B.; Verheij, E. Looking back into the future: 30 years of metabolomics at TNO. Mass Spectrom. Rev. 2013, 32, 399-415. [CrossRef]

107. Suárez-Ulloa, V.; Fernández-Tajes, J.; Manfrin, C.; Gerdol, M.; Venier, P.; Eirín-López, J. Bivalve omics: State of the art and potential applications for the biomonitoring of harmful marine compounds. Mar. Drugs 2013, 11, 4370-4389. [CrossRef]

108. Fiehn, O. Combining genomics, metabolome analysis, and biochemical modelling to understand metabolic networks. Comp. Funct. Genom. 2001, 2, 155-168. [CrossRef]

109. Jamers, A.; Blust, R.; De Coen, W. Omics in algae: Paving the way for a systems biological understanding of algal stress phenomena? Aquat. Toxicol. 2009, 92, 114-121. [CrossRef]

110. Guasch-Ferre, M.; Bhupathiraju, S.N.; Hu, F.B. Use of metabolomics in improving assessment of dietary intake. Clin. Chem. 2018, 64, 82-98. [CrossRef]

111. Goulitquer, S.; Potin, P.; Tonon, T. Mass spectrometry-based metabolomics to elucidate functions in marine organisms and ecosystems. Mar. Drugs 2012, 10, 849-880. [CrossRef]

112. Chun, S.W.; Hinze, M.E.; Skiba, M.A.; Narayan, A.R. Chemistry of a unique polyketide-like synthase. J. Am. Chem. Soc. 2018, 140, 2430-2433. [CrossRef]

113. Cho, Y.; Tsuchiya, S.; Omura, T.; Koike, K.; Oikawa, H.; Konoki, K.; Yotsu-Yamashita, M. Metabolomic study of saxitoxin analogues and biosynthetic intermediates in dinoflagellates using $15 \mathrm{~N}$-labelled sodium nitrate as a nitrogen source. Sci. Rep. 2019, 9, 3460. [CrossRef] [PubMed]

114. Gordon, B.R.; Leggat, W. Symbiodinium-Invertebrate symbioses and the role of metabolomics. Mar. Drugs 2010, 8, 2546-2568. [CrossRef] [PubMed]

115. Hillyer, K.E.; Tumanov, S.; Villas-Bôas, S.; Davy, S.K. Metabolite profiling of symbiont and host during thermal stress and bleaching in a model cnidarian-dinoflagellate symbiosis. J. Exp. Biol. 2016, 219, 516-527. [CrossRef] [PubMed]

116. Selander, E.; Kubanek, J.; Hamberg, M.; Andersson, M.X.; Cervin, G.; Pavia, H. Predator lipids induce paralytic shellfish toxins in bloom-forming algae. Proc. Natl. Acad. Sci. USA 2015, 112, 6395-6400. [CrossRef]

117. Lundholm, N.; Krock, B.; John, U.; Skov, J.; Cheng, J.; Pančić, M.; Harðardóttir, S. Induction of domoic acid production in diatoms-Types of grazers and diatoms are important. Harmful Algae 2018, 79, 64-73. [CrossRef]

118. Albinsson, M.E.; Negri, A.P.; Blackburn, S.I.; Bolch, C.J. Bacterial community affects toxin production by Gymnodinium catenatum. PLoS ONE 2014, 9, e104623. [CrossRef]

119. Sörenson, E.; Bertos-Fortis, M.; Farnelid, H.; Kremp, A.; Krüger, K.; Lindehoff, E.; Legrand, C. Consistency in microbiomes in cultures of Alexandrium species isolated from brackish and marine waters. Environ. Microbiol. Rep. 2019, 11, 425-433. [CrossRef]

120. Wang, H.; Tomasch, J.; Jarek, M.; Wagner-Döbler, I. A dual-species co-cultivation system to study the interactions between Roseobacters and dinoflagellates. Front. Microbiol 2014, 5, 311. [CrossRef]

121. Verma, A.; Barua, A.; Ruvindy, R.; Savela, H.; Ajani, P.A.; Murray, S.A. The genetic basis of toxin biosynthesis in dinoflagellates. Microorganisms 2019, 7, 222. [CrossRef]

122. Bachvaroff, T.R.; Place, A.R. From stop to start: Tandem gene arrangement, copy number and trans-splicing sites in the dinoflagellate Amphidinium carterae. PLoS ONE 2008, 3, e2929. [CrossRef] 
123. Jaeckisch, N.; Yang, I.; Wohlrab, S.; Glöckner, G.; Kroymann, J.; Vogel, H.; John, U. Comparative genomic and transcriptomic characterization of the toxigenic marine dinoflagellate Alexandrium ostenfeldii. PLoS ONE 2011, 6, e28012. [CrossRef] [PubMed]

124. Meyer, J.M.; Rödelsperger, C.; Eichholz, K.; Tillmann, U.; Cembella, A.; McGaughran, A.; John, U. Transcriptomic characterisation and genomic glimps into the toxigenic dinoflagellate Azadinium spinosum, with emphasis on polykeitde synthase genes. BMC Genom. 2015, 16, 27. [CrossRef]

125. McEwan, M.; Humayun, R.; Slamovits, C.H.; Keeling, P.J. Nuclear genome sequence survey of the dinoflagellate Heterocapsa triquetra. J. Eukaryot Microbiol. 2008, 55, 530-535. [CrossRef] [PubMed]

126. Shoguchi, E.; Shinzato, C.; Kawashima, T.; Gyoja, F.; Mungpakdee, S.; Koyanagi, R.; Hamada, M. Draft assembly of the Symbiodinium minutum nuclear genome reveals dinoflagellate gene structure. Curr. Biol. 2013, 23, 1399-1408. [CrossRef] [PubMed]

127. Aranda, M.; Li, Y.; Liew, Y.J.; Baumgarten, S.; Simakov, O.; Wilson, M.C.; Ryu, T. Genomes of coral dinoflagellate symbionts highlight evolutionary adaptations conducive to a symbiotic lifestyle. Sci. Rep. 2016, 6, 39734. [CrossRef]

128. Simam, J.; Rono, M.; Ngoi, J.; Nyonda, M.; Mok, S.; Marsh, K.; Mackinnon, M. Gene copy number variation in natural populations of Plasmodium falciparum in Eastern Africa. BMC Genom. 2018, 19, 372. [CrossRef]

129. López-Legentil, S.; Song, B.; DeTure, M.; Baden, D.G. Characterization and localization of a hybrid non-ribosomal peptide synthetase and polyketide synthase gene from the toxic dinoflagellate Karenia brevis. Mar. Biotechnol. 2010, 12, 32-41. [CrossRef]

130. Shoguchi, E.; Beedessee, G.; Tada, I.; Hisata, K.; Kawashima, T.; Takeuchi, T.; Kawachi, M. Two divergent Symbiodinium genomes reveal conservation of a gene cluster for sunscreen biosynthesis and recently lost genes. BMC Genom. 2018, 19, 458. [CrossRef]

131. Nowoshilow, S.; Schloissnig, S.; Fei, J.F.; Dahl, A.; Pang, A.W.; Pippel, M.; Winkler, S.; Hastie, A.R.; Young, G.; Roscito, J.G.; et al. The axolotl genome and the evolution of key tissue formation regulators. Nature 2018, 554, 50-55. [CrossRef]

132. Jansen, H.J.; Liem, M.; Jong-Raadsen, S.A.; Dufour, S.; Weltzien, F.A.; Swinkels, W.; Koelewijn, A.; Palstra, A.P.; Pelster, B.; Spaink, H.P.; et al. Rapid de novo assembly of the European eel genome from nanopore sequencing reads. Sci. Rep. 2017, 7, 7213. [CrossRef]

133. Bleidorn, $C$. Third generation sequencing: Technology and its potential impact on evolutionary biodiversity research. Syst. Biodivers. 2016, 14, 1-8. [CrossRef]

134. Valledor, L.; Escandón, M.; Meijón, M.; Nukarinen, E.; Cañal, M.J.; Weckwerth, W. A universal protocol for the combined isolation of metabolites, DNA, long RNAs, small RNAs, and proteins from plants and microorganisms. Plant Pathol. J. 2014, 79, 173-180. [CrossRef] [PubMed]

135. Misra, B.B.; Langefeld, C.; Olivier, M.; Cox, L.A. Integrated omics: Tools, advances and future approaches. J. Mol. Endocrinol. 2019, 62, R21-R45. [CrossRef] [PubMed]

136. Valledor, L.; Furuhashi, T.; Recuenco-Muñoz, L.; Wienkoop, S.; Weckwerth, W. System-level network analysis of nitrogen starvation and recovery in Chlamydomonas reinhardtii reveals potential new targets for increased lipid accumulation. Biotechnol. Biofuels 2014, 7, 171. [CrossRef]

(C) 2020 by the authors. Licensee MDPI, Basel, Switzerland. This article is an open access article distributed under the terms and conditions of the Creative Commons Attribution (CC BY) license (http://creativecommons.org/licenses/by/4.0/). 